\title{
Recognition on Space
}

Photographs of Structural

Elements of Baja California

GEOLOGICAL SURVEY PROFESSIONAL PAPER 718

Work done in cooperation with the National

Aeronautics and Space Administration

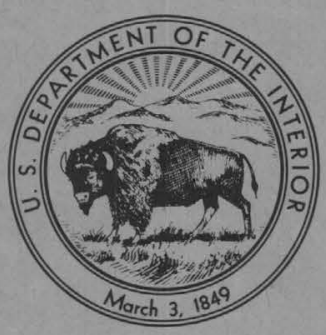





\section{Recognition on Space}

Photographs of Structural

\section{Elements of Baja California}

By WARREN HAMILTON

GEOLOGICAL SURVEY PROFESIONAL PAPER 718

Work done in cooperation with the National

Aeronautics and Space Administration

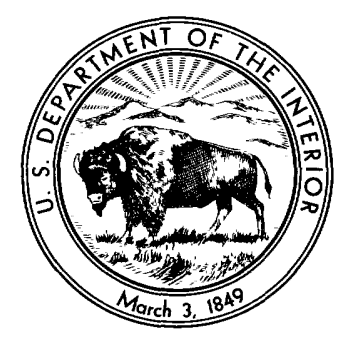

UNITED STATES GOVERNMENT PRINTING OFFICE, WASHINGTON : 1971 


\section{UNITED STATES DEPARTMENT OF THE INTERIOR}

ROGERS G. B. MORTON, Secretary

\section{GEOLOGIGAL SURVEY}

W. A. Radlinski, Acting Director

Library of Congress catalog-card No. 74-181492

For sale by the Superintendent of Documents, U.S. Government Printing Office Washington, D.C. 20402 - Price 45 cents (paper cover)

Stock Number 2401-1174 


\section{CONTENTS}

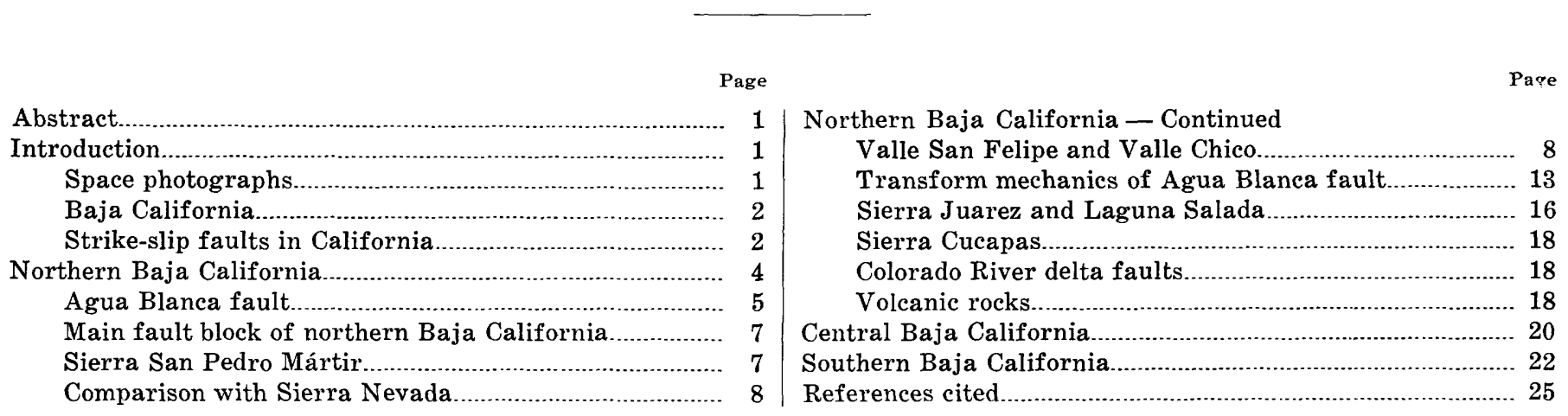

\section{ILLUSTRATIONS}

FIGURE 1. Index map..

2. Oblique photograph northward over the coast of southern California

Page

3. Sketch of area shown in figure 2 ..

4. Photograph northeastward over northeastern Baja California

5, 6. Photographs steeply downward at the Salton depression

$7,8,9,10$. Vertical space photographs of northern Baja California, mounted for stereoscopic viewing .................10,11, 12, 13

11. Map of part of Baja California, showing Quaternary structures visible on space photographs........................... 14

12. Map showing vectors of relative motion of the crustal plate south of the Agua Blanca fault............................ 15

13. Oblique photographs of the southern part of northern Baja California............................................................... 17

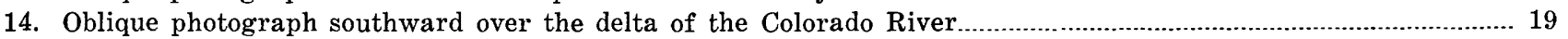

15. Oblique photograph of the mouth of the Colorado River $\ldots$

16. Photograph steeply downward over Rosario-Santa Maria sector of Baja California.......................................... 21

17. Oblique photograph southeastward down the Gulf of California

18. Oblique photograph northwestward over Isla Tiburón to Baja California

19. Map showing possible strike-slip faults of central and southern Baja California.............................................. 24

20. Photograph steeply downward to La Paz region 



\title{
RECOGNITION ON SPACE PHOTOGRAPHS OF STRUCTURAL ELEMENTS OF BAJA CALIFORNIA
}

\author{
By WARREN HAMILTON
}

\begin{abstract}
Photographs of Baja California taken from space - by astronauts using hand-held cameras on various Gemini and Apollo missions and by automatic camera on the Apollo 6 flight - provide many illustrations of known structural features of the peninsula and also reveal some structures that had not been recognized previously. Although the space photographs provide no data that could not be obtained, and in much more detail, by ground mapping and by the interpretation of conventional aerial photographs, it is obvious that space photography will provide a valuable reconnaissance tool when pictures made from space with mapping cameras eventually become available.
\end{abstract}

An apparent transform relationship between strike-slip and normal faulting is illustrated by the overlapping vertical photographs from Apollo 6 of northern Baja California. The active Agua Blanca right-lateral strike-slip fault, known to have a Quaternary displacement of at least 5 kilometers, trends east-southeastward to end at the north end of the deeply alluviated north-northwest-trending half graben of Valle San Felipe and Valle Chico. The crustal plate bounded on the north by the strike-slip fault is bounded on the east by the east-facing normal-fault scarp of the Sierra San Pedro Mártir; the normal fault has a vertical offset of about 5 kilometers and requires at least 4 kilometers of horizontal extension. The Agua Blanca fault appears to be a transform to that crustal extension.

The uplands of the high Sierra San Pedro Mártir are seen on the photographs to be a low-relief surface deformed by young faults, monoclines, and warps, which mostly produce west-facing steps and slopes. The topography is basically structural, not erosional. The west-facing topographic steps of the older and more eroded west slope of the Sierra Nevada of California may have a similar structural origin.

The Sierra Cucapas of northeasternmost Baja California and the Colorado River delta of northwesternmost Sonora are seen to be broken by northwest-trending strike-slip faults, which belong to the same family as the Elsinore and San Jacinto fault systems of southwestern California.

Space-photograph coverage of central and southern Baja California is poor. No strike-slip faults were recognized in the central region. In the southern region, however, a strikeslip fault is inferred to trend northward obliquely across the tip of the peninsula from near Cabo San Lucas to La Paz, thence offshore along the east coast until it comes ashore again as the Bahía Concepción strike-slip fault.

\section{INTRODUCTION}

The internal structure of Baja California, Merico, is of significance because the peninsula now belongs to the great tectonic plate of the Pacific Ocean floor west of the crest of the East Pacific Rise rather than to the North American plate. The Pacific plate is now moving about $6 \mathrm{~cm}$ (centimeters) per year relatively northwestward past the North American plate, the boundary between the two plates being tre strike-slip San Andreas fault system in California and the oblique-extension Gulf of California rif.t through the continental mass in Mexico (Isacks and others, 1968; Larson and others, 1968; Le Pichon, 1968; Morgan, 1968).

Photographs of Baja California taken from space - by astronauts using hand-held cameras during several Gemini and Apollo flights and by an automatic camera during the unmanned Apollo 6 mission - show structural features important $\mathrm{fc}$ : an understanding of the Cenozoic development of the peninsula. These features, and particularly strike-slip faults and related structures, are discusser in this report. Most of the structures described have been identified by other geologists by surface geologic mapping and by interpretation of conventional aerial photographs, but some have not been recognized previously.

\section{SPACE PHOTOGRAPHS}

The space photographs of Baja California vary widely in quality and utility. Photography was a major purpose only during the Apollo 6 mission, when an automatic camera on an unmanned vehicle took overlapping vertical photographs in a single strip across Baja California and the southwestern United States; the pictures can be viewed stereoscopically, and they provide far more information than do those of any other Apollo or Gemini missions. Some astronauts on the manned flights pro- 
duced excellent pictures, but some missions produced almost no geologically useful photographs. Even the best of the hand-held pictures are taken at random horizontal and vertical angles. The cameras - 70$\mathrm{mm}$ (millimeter) Hasselblads, modified to operate almost like box cameras - used on the Gemini flights were described by Nathan (1969) and Underwood (1968). The automatic camera on the unmanned Apollo 6 flight was a 76-mm Navy airplane-wing "gun" camera (a Maurer 220G, modified to use 70$\mathrm{mm}$ film). No mapping camera has yet been used in nonmilitary space flights. Many space photographs have been published in popular books and articles: see, for example, Cortright (1968), Lowman (1966, 1968), and National Aeronautics and Space Administration (1967).

The transparencies and prints generally available for scientific study are two or three copy-steps removed from the original transparencies. Much degradation of both color quality and resolution is necessarily introduced by these steps. That the original transparencies hold far more information than do the copies is made clear by the reproductions in the volume by Lowman (1968): these $26 \times 26-\mathrm{cm}$ color plates were published from prints made with great care directly from the original transparencies, and even though degraded by the publication process contain more detail than do most prints and transparencies currently available for scientific study.

The overlapping vertical photographs from Apollo 6 vividly demonstrate, despite their rather low resolution, the potential value of space photography for tectonic interpretation. When vertical space photography with mapping cameras becomes available, we will learn much that is new about tectonics, particularly of the arid regions of the world. The hand-held through-the-window space snapshots from the manned flights, however, are useful primarily as illustrations, not as serious scientific tools.

Figure 1 shows the localities covered by the space photographs in this report. The vertical photographs of the Apollo 6 strip across Baja California are reproduced in black and white in figures $7,8,9$, and 10, and the best of the hand-held Gemini and Apollo pictures are presented as black-and-white figures. The useful hand-held photographs are mostly those taken steeply downward. The many low-angle photographs of the peninsula mostly convey little geologic information and will not be discussed in this report.

\section{BAJA CALIFORNIA}

The term "Baja California" as used here refers to the entire peninsula, including the Mex: can portions of the Peninsular Ranges and of the desert west of the Colorado River. The geology of Baja California has been summarized by Beal (1948), and in less detail but with incorporation of newer information by Allison (1964).

A field and aerial-photograph reconnaissance of the north half of the peninsula has been made in the last decade by R. G. Gastil, the late E. C. Allison, and their associates and students, mostly at the San Diego State College. Little of their work has yet been published, but brief summaries include those by Allison (1964), Gastil (1968), Gastil, Allison, Phillips, and Obregon (1969), and Gastil, Allison, and Phillips (1969a). Gastil generously gave me an unpublished 1:500,000 geologic map of the peninsula north of the 28th parallel that was compiled by himself, E. C. Allison, and others; generalized contacts, but not structure, from this map appear on the new geologic map of Mexico (Hernández-S.-M. and Salas, 1968).

I have had the opportunity during two brief tours to see in the field many of the structural features in northern Baja California that are referred to here. Field impressions have, of course, influenced my interpretations of the space photograprs. I have not visited the rest of Baja California.

STRIKE-SLIP FAULTS IN CALIFORNIA

Inasmuch as southern California contains known major strike-slip faults (see geologic maps by Dibblee, 1967 ; Jennings, 1967 ; Rogers, 1966 ; and Strand, 1962), it is appropriate to look at the space photographs of these faults to determine the criteria by which such faults can be recognized on pictures of the quality now available. The maximum latitude reached by orbits of Gemini satellites was about $34^{\circ}$ - the latitude of Los Angeles - and mo of the space photographs are low-angle obliques looking into California from points considerably south of this limit. One of the best of these oblique photographs is reproduced as figure 2 (fig. 3 stows geographical and geologic features in fig. 2), and one of several obliques that provide a view northeastward over the Salton Sea is given as figure 4. Handheld space photographs taken steeply downward at the region of the Salton depression of southeastern California (figs. 5, 6) provide better detail. 


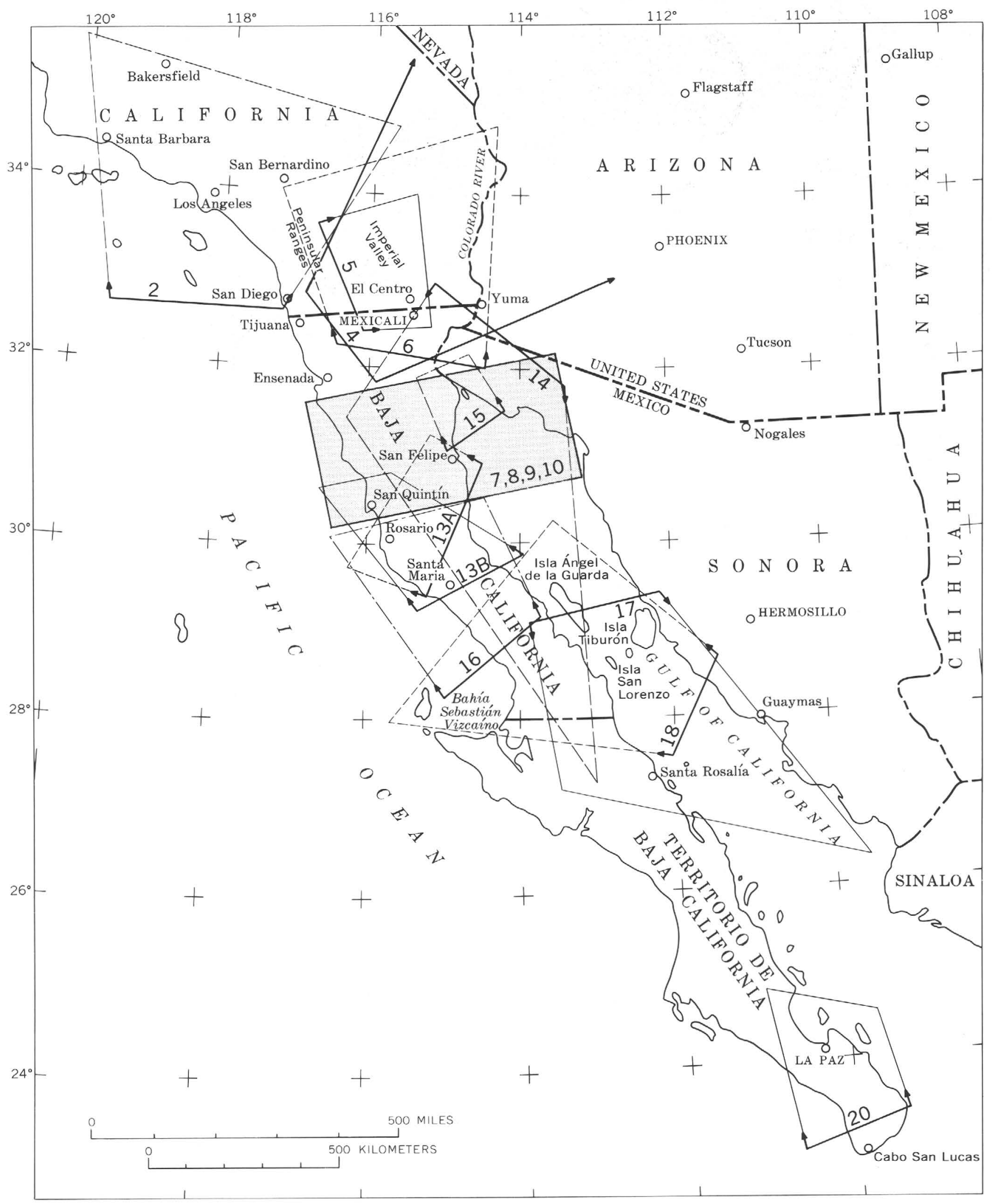

FIGURE 1. - Baja California and southern California, showing localities covered by space photographs in this report. 


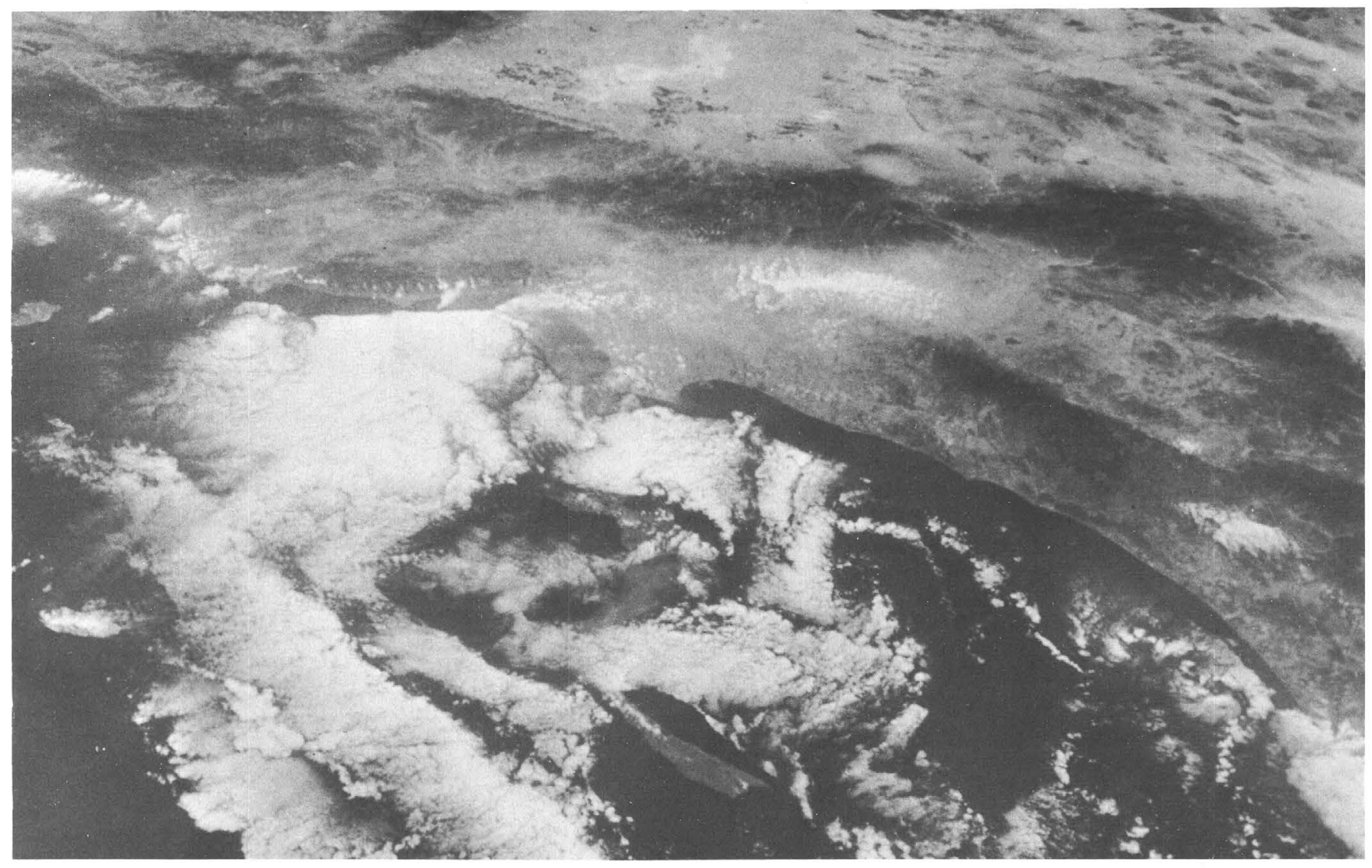

FIGURE 2. - View northward over the coast of southern California, showing the appearance from a distance of the major right-lateral northwest-trending fault zones. The San Andreas fault zone is visible along much of its course west-northwest of Cajon Pass as the trough between linear mountain fronts and low, narrow uplifts, but it cannot be identified southeast of the pass. The Elsinore and San Jacinto fault zones are conspicuous as alined topographic elements and as lines of color change. The strong northwest-trending topographic alinements of the Mojave Desert beyond the San Bernardino Mountains may be due to middle or late Tertiary strike-slip faults, now inactive. The position of the left-lateral, northeast-trending Garlock fault is marked in figure 3, but the structure is not conspicuous on the photograph. About $300 \mathrm{~km}$ of coastline appear in the picture. Apollo 7 photograph, AS7-11-2021, 1968. (Frames 2020 and 2022 are similar.)

The comparison of structures visible on the space photographs with geologically mapped strikeslip faults indicates that in pictures of comparable resolution in desert regions elsewhere, strike-slip faults are likely to be recognizable where they produce straight mountain fronts, alined canyons, and narrow, straight uplifts, and they are unlikely to be visible where they cross alluvial terranes of low relief.

\section{NORTHERN BAJA CALIFORNIA}

Many young structural features (fig. 11) of the northern part of Baja California are visible on the space photographs. Most of these structures are known from surface geologic mapping, but some have not been recognized previously. The most useful of the photographs of this region are the overlapping vertical pictures taken by unmanned satel- lite Apollo 6 (figs. 7, 8, 9, 10). The photographs were made on 70-mm positive color film; paper prints can be studied stereoscopically. Much of the same area is depicted also on hand-held photographs taken steeply downward during several manned Gemini and Apollo flights on orbits that crossed the peninsula on almost the same track as that of Apollo 6 . The best of the hand-held pictures have good resolution, color, and sun angles; but because they cannot be viewed stereoscopically, they are less useful than the overlapping vertical photographs.

Comparison of the Apollo and Gemini photographs with the unpublished 1:500,000 geologic map of northern Baja California by R. G. Gastil, E. C. Allison, and others demonstrates that in the desert region, extending east from the crest of the Sierra San Pedro Mártir to the Gulf of California, many contacts between metamorphic rocks, granitic rocks, 


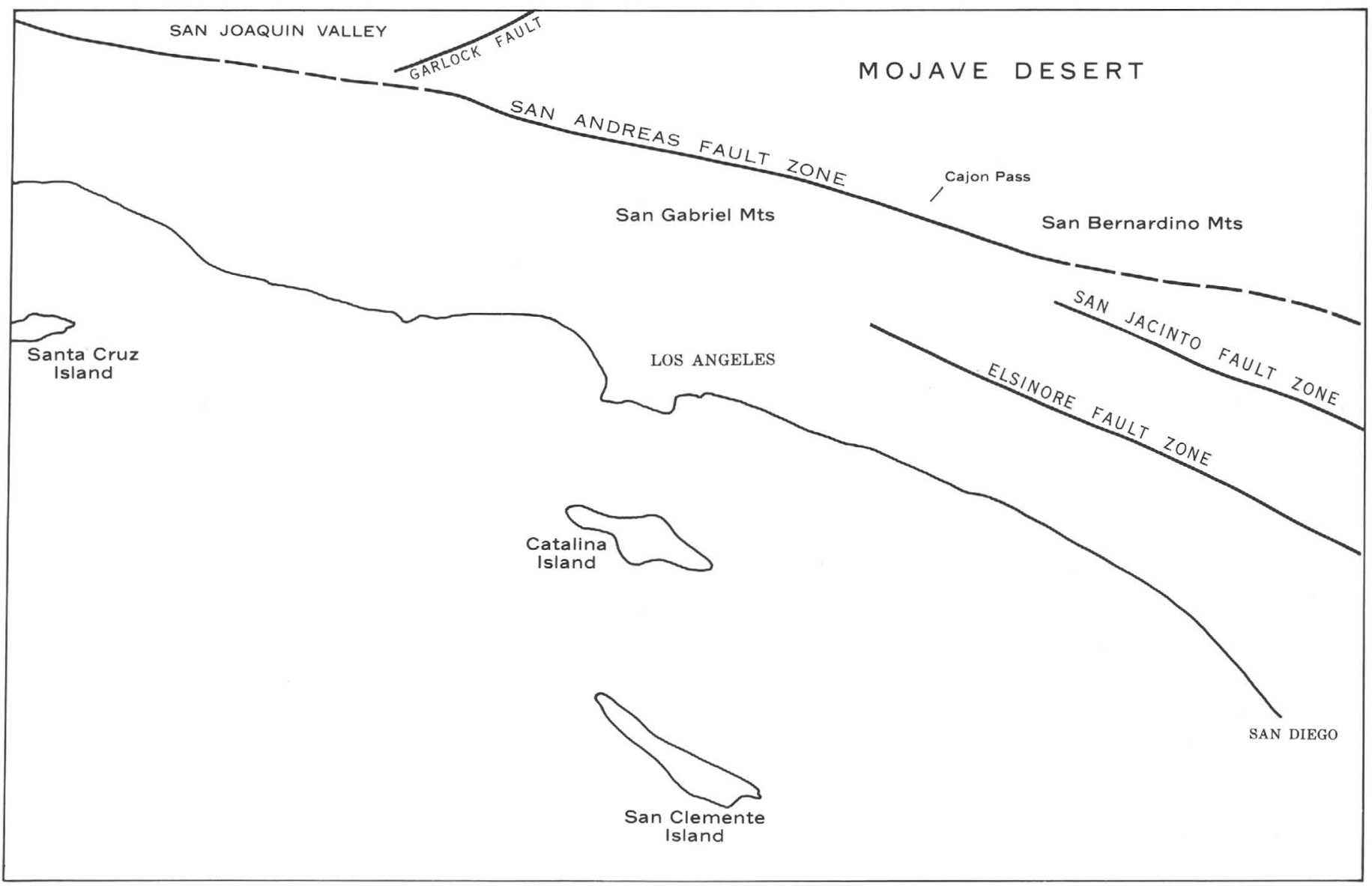

FIGURE 3. - Geologic and geographic features of area shown in figure 2.

and Tertiary volcanic rocks are easily recognized on the pictures. On the scrub-covered west slope, from the range crest to the coast, some areas of granitic rocks can be recognized on the photographs, but contacts with pregranitic metamorphic rocks, postgranitic basalts, and other units cannot generally be identified.

\section{AGUA BLANCA FAULT}

The Agua Blanca right-lateral strike-slip fault (figs. 11, 12) trends west-northwestward across Baja California from Valle San Felipe to the Pacific coast south of Ensenada. Allen, Silver, and Stehli (1960) found Holocene stream offsets, typically of about $50 \mathrm{~m}$ (meters), to be shown along most of the fault westward from central Valle Trinidad and displacements of older surficial features, not dated within the Pleistocene, to reach at least $270 \mathrm{~m}$ for stream valleys and $5 \mathrm{~km}$ (kilometers) for alluvial fans. The fault may have broken at the surface during the very severe earthquake of 1892 (Shor and Roberts, 1958). Total displacement is not established; Allen, Silver, and Stehli suggested a possible offset of
$11 \mathrm{~km}$ between granitic rocks in a sliver in the fault and those outside the fault, and a less likely offset of $22 \mathrm{~km}$ between rocks of another sliver and wallrocks, but no rocks have yet been matched across the fault. The unpublished 1 : 500,000 reconnaissance geologic map by R. G. Gastil, E. C. Allison, and others does not suggest that large displacement is probable; one possible indicator, the narrow west coastal belt of Upper Cretaceous (postbatholith) strata, shows an apparent offset of only 10 or $15 \mathrm{~km}$. The fault may be entirely of Quaternary age.

The Agua Blanca fault throughout its length lies within a topographic depression (figs. 7, 8). Such depressions are characteristic of strike-slip faults across mountainous terrain, and probably are due as much to lateral transport of varying topography as to erosion along fault zones. The depression is narrow except near its ends. In the west, Bahía de Todos Santos and its small coastal plain are bounded on the south by the fault. Near the east end of the fault, the plain of Valle Trinidad extends south from the fault to an irregular boundary against faulted highlands. No Holocene faulting was recognized along 


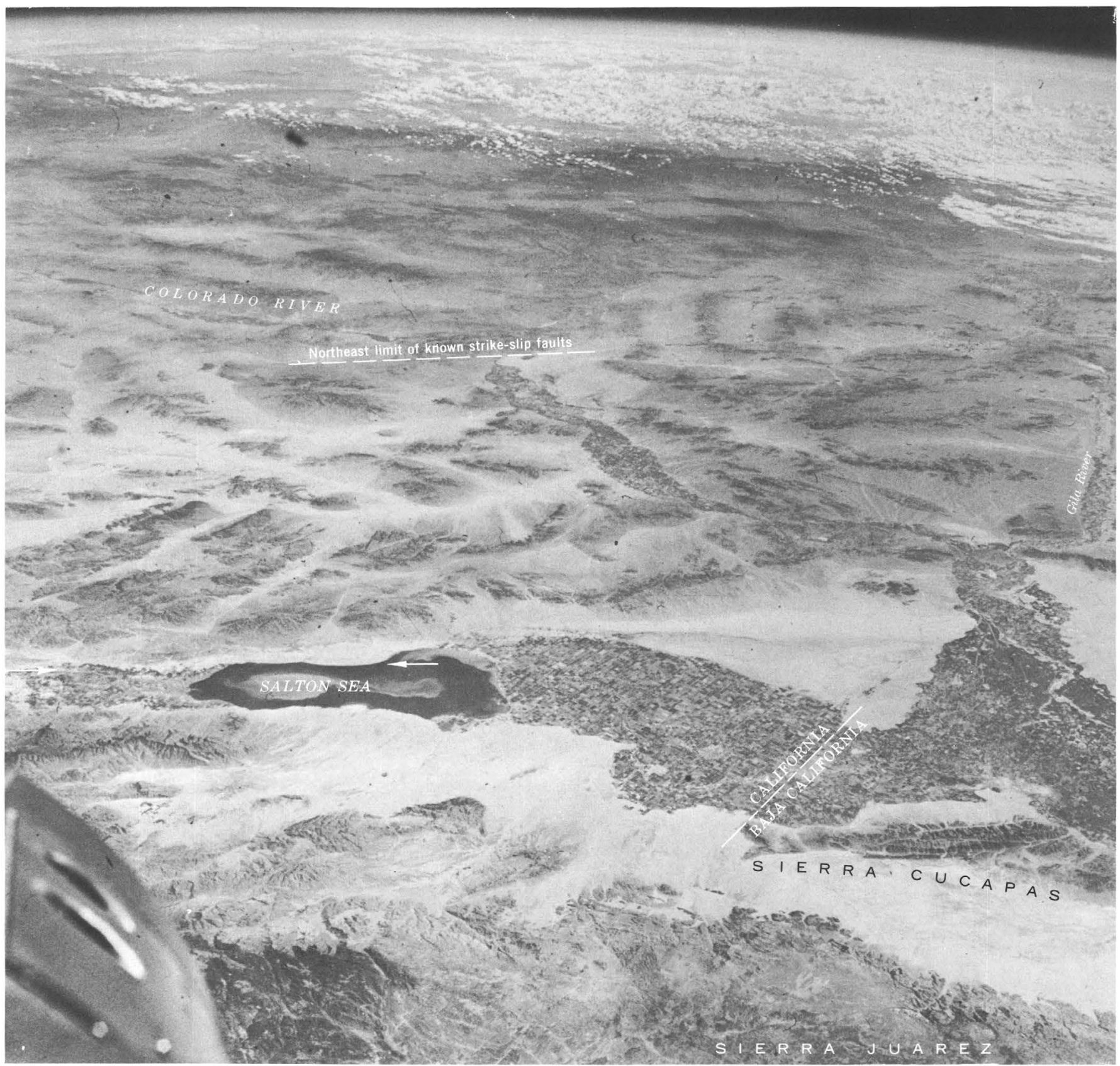

FIGURE 4. - Photograph northeastward over northeastern Baja California and southeastern California to Arizona and beyond. The position of the San Andreas fault is marked by arrows; the fault can be detected on the picture only as the contact between light alluvium and dark mountains (mostly upper Cenozoic sediments) at the left edge of the photograph; the fault is not visible in the alluvium along the northeast side of the Salton Sea. Several faults of the San Jacinto and Elsinore zones of right-lateral faults produce linear mountain fronts and other alined topographic features in the lower left part of the picture, but like the San Andreas they cannot be identified away from mountain fronts or linear fault valleys. The alined longitudinal canyons of the Sierra Cucapas probably mark strike-slip faults. The low mountain ranges between the San Andreas fault and the northeast limit of known strike-slip faults may be outlined mostly by strike-slip faults - east-trending left-lateral faults and northwest-trending right-lateral ones - but no direct evidence for this interpretation is apparent on the photograph. Gemini V photograph, magazine 1, frame 13 (NASA numbers S-65-45382 for black and white, S-65-45747 for color), taken 22 August 1965 by L. G. Cooper and Charles Conrad, Jr. 
the fault by Allen, Silver, and Stehli (1960) in the eastern part of that plain or in the pass through which the fault projects into Valle San Felipe.

The trace of the Agua Blanca fault - as distinguished from the conspicuous narrow valley which it typically occupies - is visible on the space photographs primarily in the $50-\mathrm{km}$ sector centered on Santo Tomás (fig. 7). The active trace of the fault in this sector leaves the valley floor in several places to trend along the lower wall of first one side of the valley and then the other, and to cut across low hills. Wherever the fault occurs thus on the sidewalls, the canyons draining into the valley are offset, and the drainage pattern above the fault trace does not correspond to that below. The resolution of the photographs is adequate to show clearly the truncation and dissimilarity of the now-juxtaposed drainages but is not quite good enough to allow picking of precise matches of canyons which should once have been continuous: the right-lateral character of the fault, obvious on the ground, cannot be read with confidence from the photographs. The fault trace crosses parts of the plain of Valle Trinidad but cannot be certainly identified across the flat areas, although its position is apparent from the alinement of the faulttrace valleys at opposite ends of the plain and from the straight mountain fronts along parts of the Valle Trinidad on the line projected between these valleys (figs. 7, 8).

\section{MAIN FAULT BLOCK OF NORTHERN BAJA CALIFORNIA}

The western two-thirds of the northern part of Baja California consists of a westward-tilted fault block. The high eastern part of the block south of the Agua Blanca fault is the Sierra San Pedro Mártir, which faces the Gulf of California as an imposing scarp. The crest is lower and more diffuse north of the Agua Blanca fault, but still farther north the Sierra Juarez rises and in its turn gains a high east-facing boundary scarp.

The dominant rocks are granitic and yield Late Cretaceous and late Early Cretaceous radiometric age determinations, insofar as they have been dated (Estavillo and Rogers, 1970; Krummenacher and Gastil, 1970; Silver and others, 1969). Contacts between granitic, metamorphic, and young volcanic rocks on the western slope are not, in general, apparent on the space photographs, although the larger areas of exposed granitic rocks can generally be recognized by their joint-controlled rectangular or arcuate drainage patterns.
SIERRA SAN PEDRO MÁRTIR

The surface altitude of the main fault block south of the Agua Blanca fault rises irregularly eastward to a level of $1,000-1,500 \mathrm{~m}$ at the west side of the Sierra San Pedro Mártir proper. Faults and warps in that area step the surface upward. The crest of the range, at the top of the bounding eastfacing scarp, has altitudes of $2,000-3,100 \mathrm{~m}$ and includes the highest peaks in Baja California.

The late Cenozoic internal structure of the Sierra San Pedro Mártir as depicted on the map (fig. 11) is interpreted from stereoscopic study of the space photographs (fig. 8). The Sierran uplands are so little dissected that they cannot long have had their present high altitude and bounding scarps; the topography probably is primarily due to Quaternary and (?) very late Tertiary uplift and deformation of a low-relief surface. The aspect of the surface is that of structural, not erosional, topography. West of the range crest, steep scarps give way along strike to gentler slopes: normal faults apparently grade into monoclines. A dome gives way along strike to a convex break in slope, apparently as an anticlinal axis grades into the flexure at the top of a monocline, and a broad topographic low gives way to a concave break in slope as a syncline becomes a flexure at the bottom of a monocline.

The low-relief erosion surface was once widely covered by thin Eocene and Paleocene deposits (Gastil and others, 1969a) and, hence, dates from the Late Cretaceous or earliest Tertiary.

The east face of the Sierra San Pedro Mártir is one of the most imposing fault scarps in North America. The 2,000- to 3,000-m crest of the range is along the top of the scarp, which falls steeply to the alluvial fans at an altitude of $500 \mathrm{~m}$. The crest is only $10 \mathrm{~km}$ from the fans 1.5 to $2.5 \mathrm{~km}$ below. High cliffs and extremely rugged canyons characterize the upper and most-eroded part of the scarp. The lower part of the scarp maintains valley-facing slopes of $30^{\circ}$ for altitude gains of $1 \mathrm{~km}$ in many places. The base of the scarp appears on the space photographs to mark a single fault trace.

Incised canyons high on the scarp are alined subparallel to the range crest, and altitudes of the east rims of these canyons appear on the space photographs (fig. 8) to be anomalously high. The interpretation is made in figure 11 that these canyons mark a west-facing normal fault on the east-facing scarp ; but the alined canyons might instead be products of erosion of the upper, longest exposed part of the main fault scarp. 


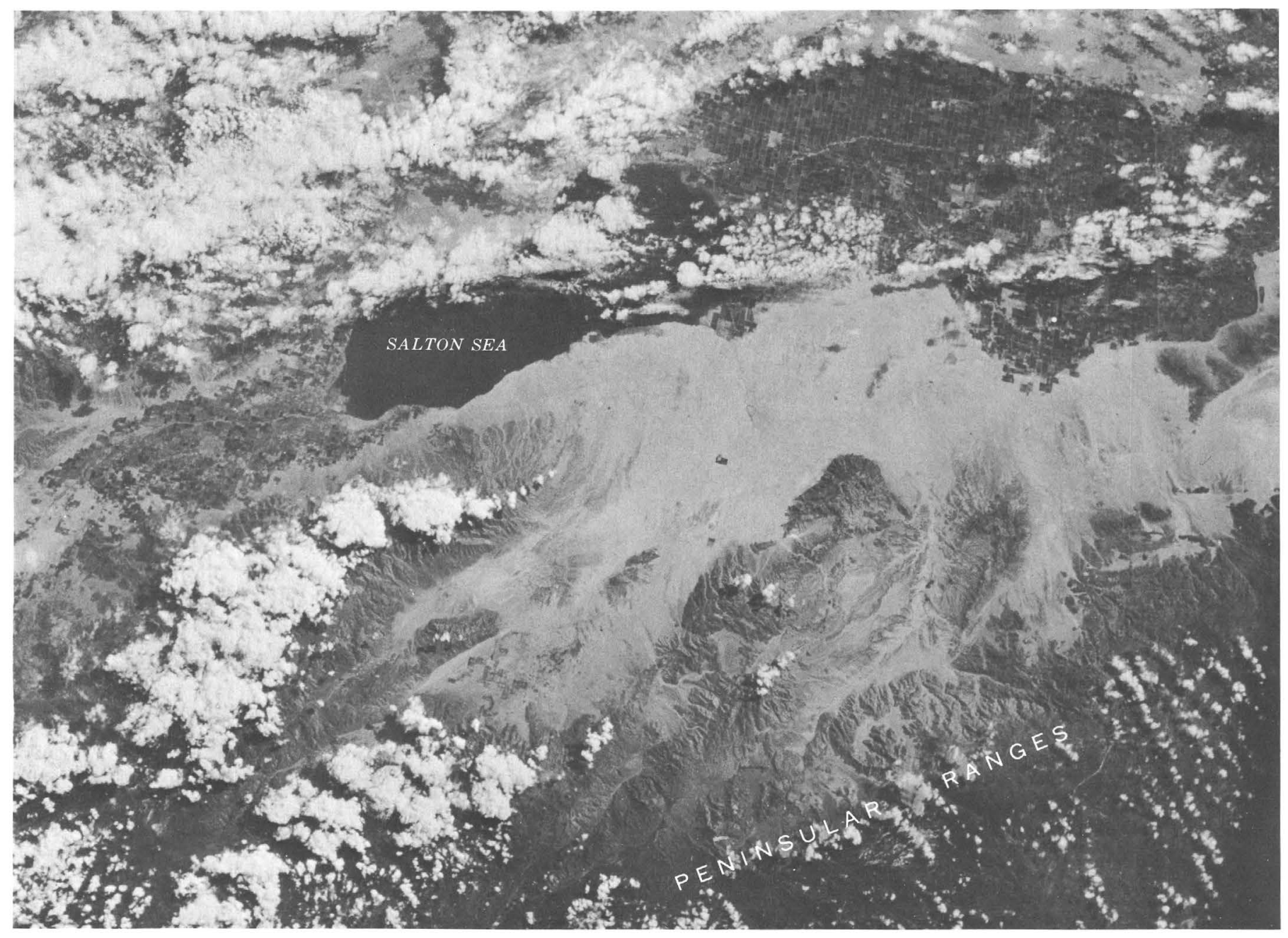

FIGURE 5. - Photograph looking steeply downward at the Salton depression, southern California and northern Baja California. Some of the known right-lateral faults of the San Jacinto and Elsinore fault zones are apparent as range-front alinements trending northwestward (toward lower left), but the faults are not visible in surficial deposits. Apollo 9 photograph AS9-22-3437, 9 March 1969.

\section{COMPARISON WITH SIERRA NEVADA}

The main fault block of northern Baja California is comparable to the Sierra Nevada of California, although it is not quite so wide or high. It is less dissected than the Sierra Nevada, and its drainage is much less integrated; so presumably the Baja California uplift is largely younger than the California one, although climatic differences must account for some of this contrast.

The west slope of the Sierra Nevada displays several west-facing topographic steps, eroded back in irregular patterns. Bateman and Wahrhaftig (1966, p. 149-154) summarized the controversy in the literature regarding these steps, presented new data, and concluded that the steps are due to weath- ering and erosion of an initially more uniform slope. The much younger, uneroded steps of the Sierra San Pedro Mártir appear to be structural, formed by monoclinal warping and normal faulting.

VALLE SAN FELIPE AND VALLE ChICo

The fault trough of Valle San Felipe and Valle Chico extends along the east base of the Sierra San Pedro Mártir. The trough is mostly $10-20 \mathrm{~km}$ wide, its single-fault west boundary contrasting markedly with the topographic complexity of its irregular east boundary, which is defined by small mountain masses faulted against and buried beneath it (fig. 9). The valley is filled with upper Cenozoic marine and nonmarine sedimentary and volcanic rocks, which gravity and magnetic data suggest to be about 2.5 $\mathrm{km}$ thick in the center of the trough (Slyker, 1969). 


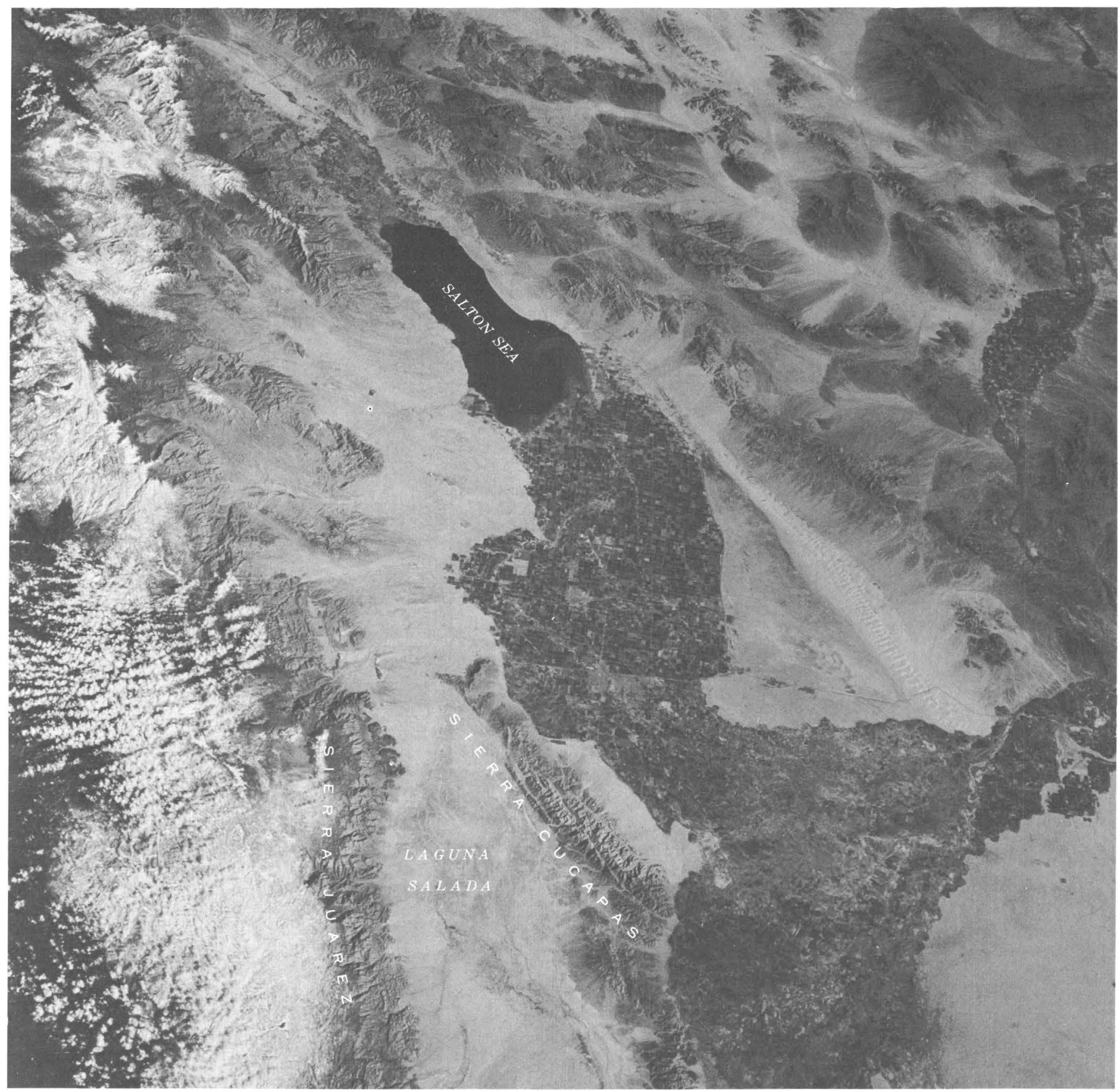

Figure 6. - Photograph looking steeply downward at the Salton depression, southern California and northern Baja California. The alined canyons of the Sierra Cucapas (lower center) mark strike-slip faults. The high normal-fault scarp of the Sierra Juarez is obvious at lower left. The San Andreas fault trends northwestward (toward upper left, across upper third of picture) but is not apparent on the photograph. The ranges northeast (above and right) of the San Andreas may be outlined primarily by strike-slip faults, but these cannot be identified in the picture. Apollo 9 photograph AS9-23-3558, 11 March 1969.

The total structural relief on the normal-fault system is thus about $5 \mathrm{~km}$, from Sierra crest to basement floor of trough.

The great normal fault bounding the valley on the west requires crustal extension. The amount de- pends upon the configuration of the normal fault at depth. A conventional assumption of a $50^{\circ}$ dip on the fault requires about $4 \mathrm{~km}$ of horizontal extension to account for the $5 \mathrm{~km}$ of vertical off set. The alternative assumption, which I prefer, that the fault 


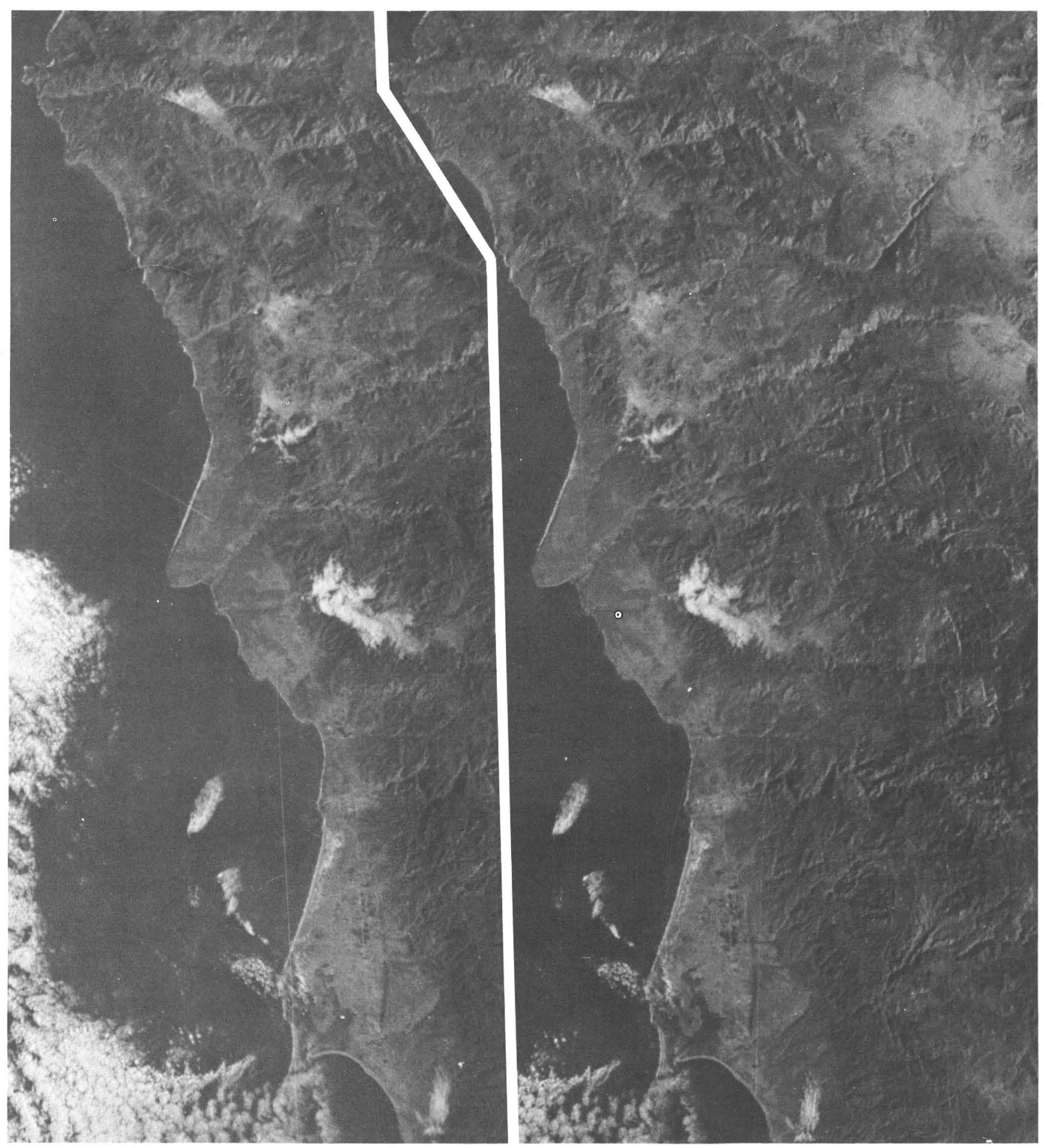

FIGURE 7. - Vertical space photographs of northern Baja California, mounted for stereoscopic viewing. Overlaps on right with figure 8. Apollo 6 photographs AS6-2-1432 (left) and 1433.

flattens downward, requires more extension, perhaps as much as $10 \mathrm{~km}$.

The Agua Blanca fault apparently enters the north end of the Valle San Felipe from the westnorthwest (fig. 8). (R. G. Gastil (oral commun.,
1970), however, emphasizes that no major fault has yet been proved by fieldwork to be present in the pass through which the fault projects from Valle Trinidad to Valle San Felipe.) It is apparent from field study (Slyker, 1969), from interpretation of 

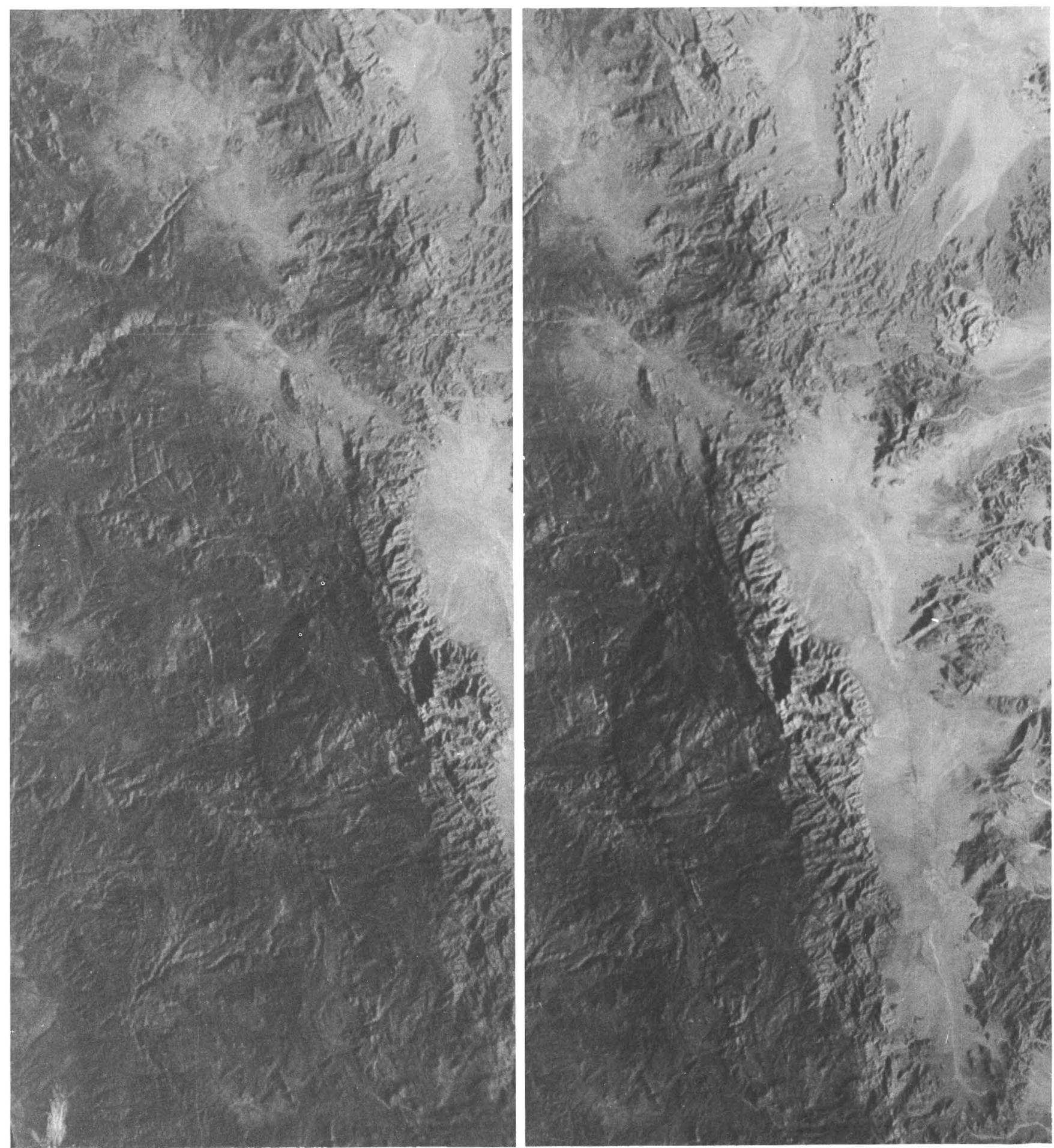

FIGURE 8. - Vertical space photographs of northern Baja California, mounted for stereoscopic viewing. Overlaps on left with figure 7 and on right with figure 9. Apollo 6 photographs AS6-2-1433 (left) and 1434.

conventional aerial photographs (R. G. Gastil and others, unpub. map), and from interpretation of the space photographs that the fault does not cross the low ranges on strike to the east-southeast on the east side of Valle San Felipe (figs. 8, 9).
The low ranges of granitic, metamorphic, and volcanic rocks east and north of the Valle San Felipe-Valle Chico trough display many conspicuous fault scarps. The interpretation of these faults in figure 11 is conservative, as can be seen from the 

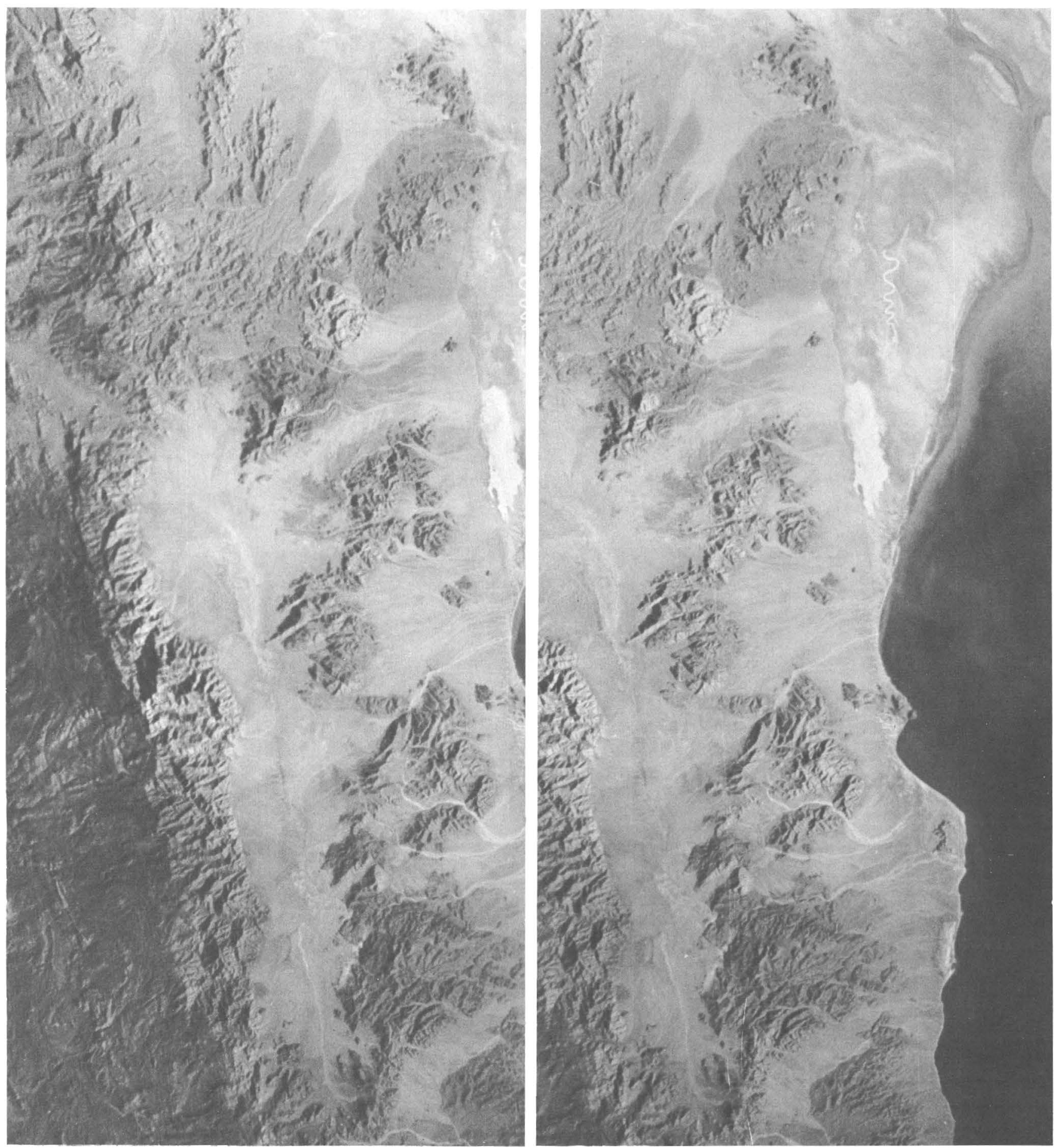

FIGURE 9. - Vertical space photographs of northern Baja California, mounted for stereoscopic viewing. Overlaps on left with figure 8 and on right with figure 10. Apollo 6 photographs AS6-2-1434 (left) and 1435.

space photographs of figure 9 ; these are little-eroded fault scarps, 100-800 $\mathrm{m}$ high. Many other faults, some smaller and others older and more subdued, could be inferred also. The dominant trend of the young normal faults is northeastward. The topographic relationships of several of these northeasttrending structures are such that the faults might be largely left-lateral rather than normal. 

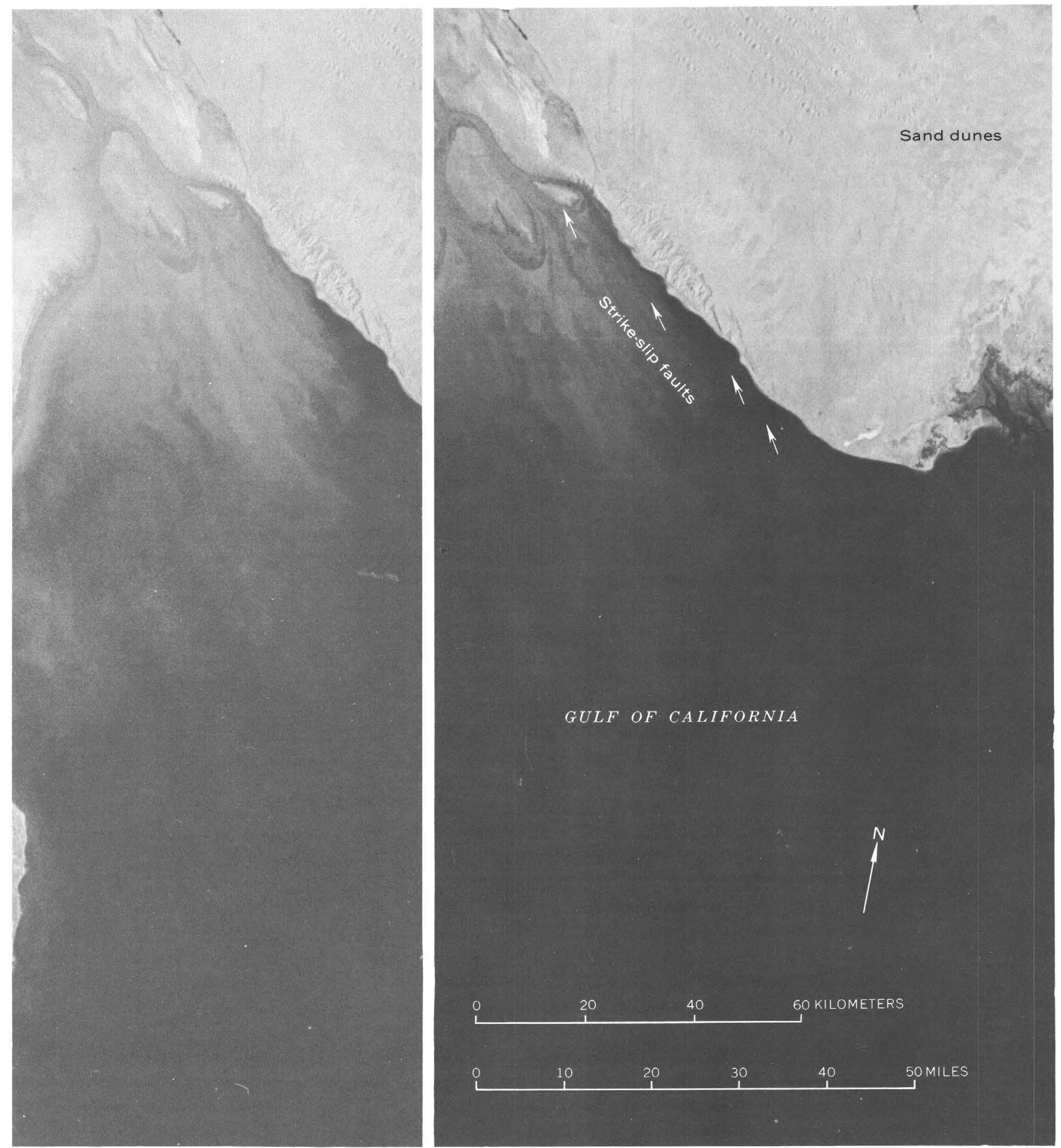

FIGURE 10. - Vertical space photographs of northern Baja California, mounted for stereoscopic viewing. Overlaps on left with figure 9. Apollo 6 photographs AS6-2-1435 (left) and 1436.

TRANSFORM MECHANICS OF AGUA BLANCA FAULT

All strike-slip faults must be transform fäults, in the broad sense of the term proposed by Wilson (1965), for all must give way at both ends to ten- sion or compression by which the strike-slip motion is absorbed. In Wilson's original use of the term, a transform fault shifts extension (in the specific form of a spreading midocean ridge) from one side of the 


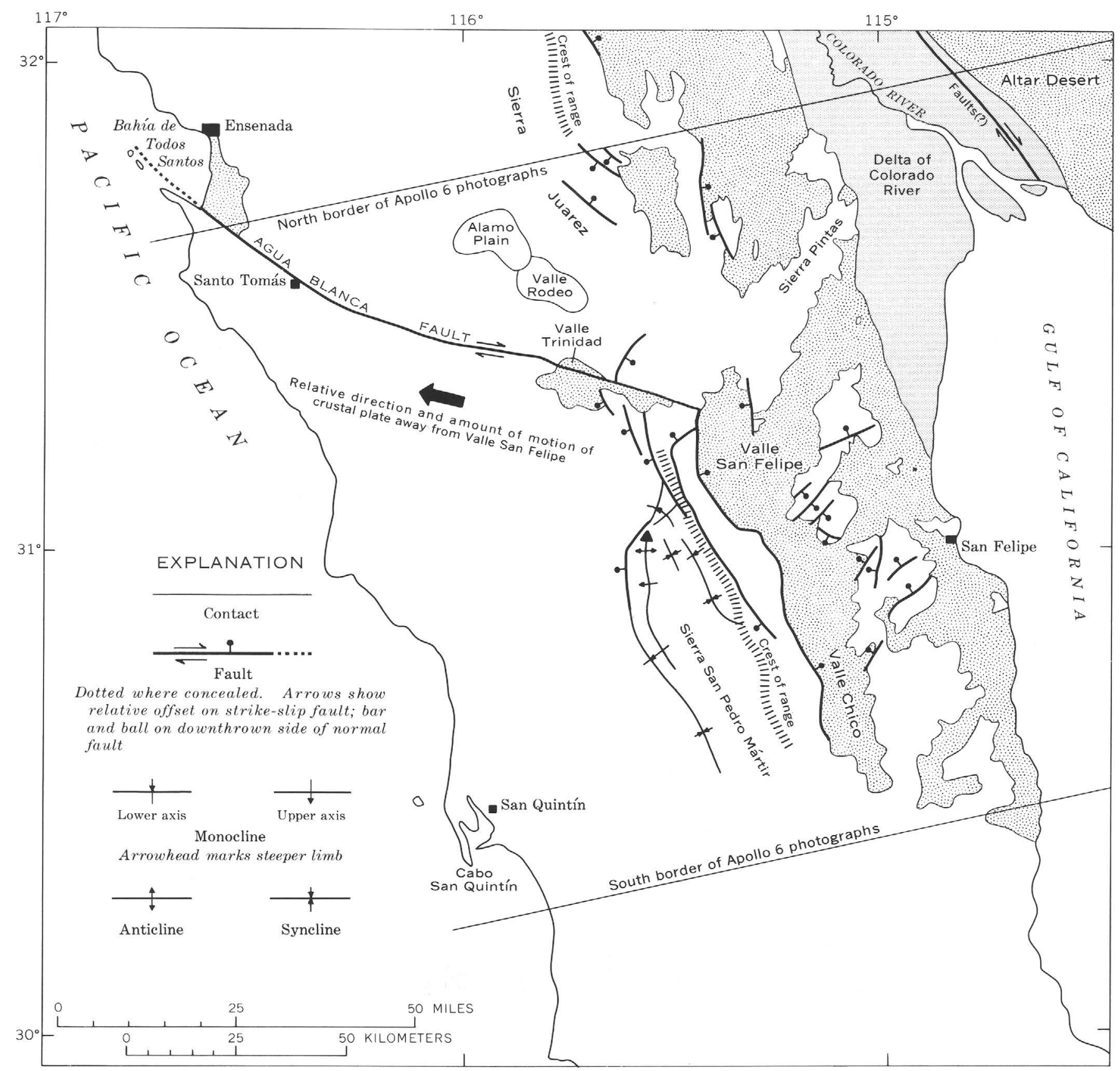

Figure 11. - Part of Baja, California, showing Quaternary structures visible on space photographs. Areas of Quaternary sediments, mostly continental, are stippled; Colorado River delta is shaded.

fault at one end to the opposite side at the other end. Other variants are possible. A transform in a compressive system can shift shortening from one side at one end to the opposite side at the other end. Or, shortening and extension can occur at opposite ends of the same side of a transform. Compression and tension can be either abrupt or distributed.

The Agua Blanca fault has a right-lateral displacement of at least $5 \mathrm{~km}$. It does not cut the hills east of Valle San Felipe, so the displacement must be absorbed in extension or compression somewhere west of those hills. (R. G. Gastil (written commun., 1969) has arrived at conclusions similar to those presented here.) The fault was vigorously active in late Quaternary time, so hypothetical cross structures cannot be called upon to displace it out of sight. Transform relationships must be sought.

Three normal faults trend southward from the plain of Valle Trinidad. The extension represented by these faults presumably has absorbed some of the 


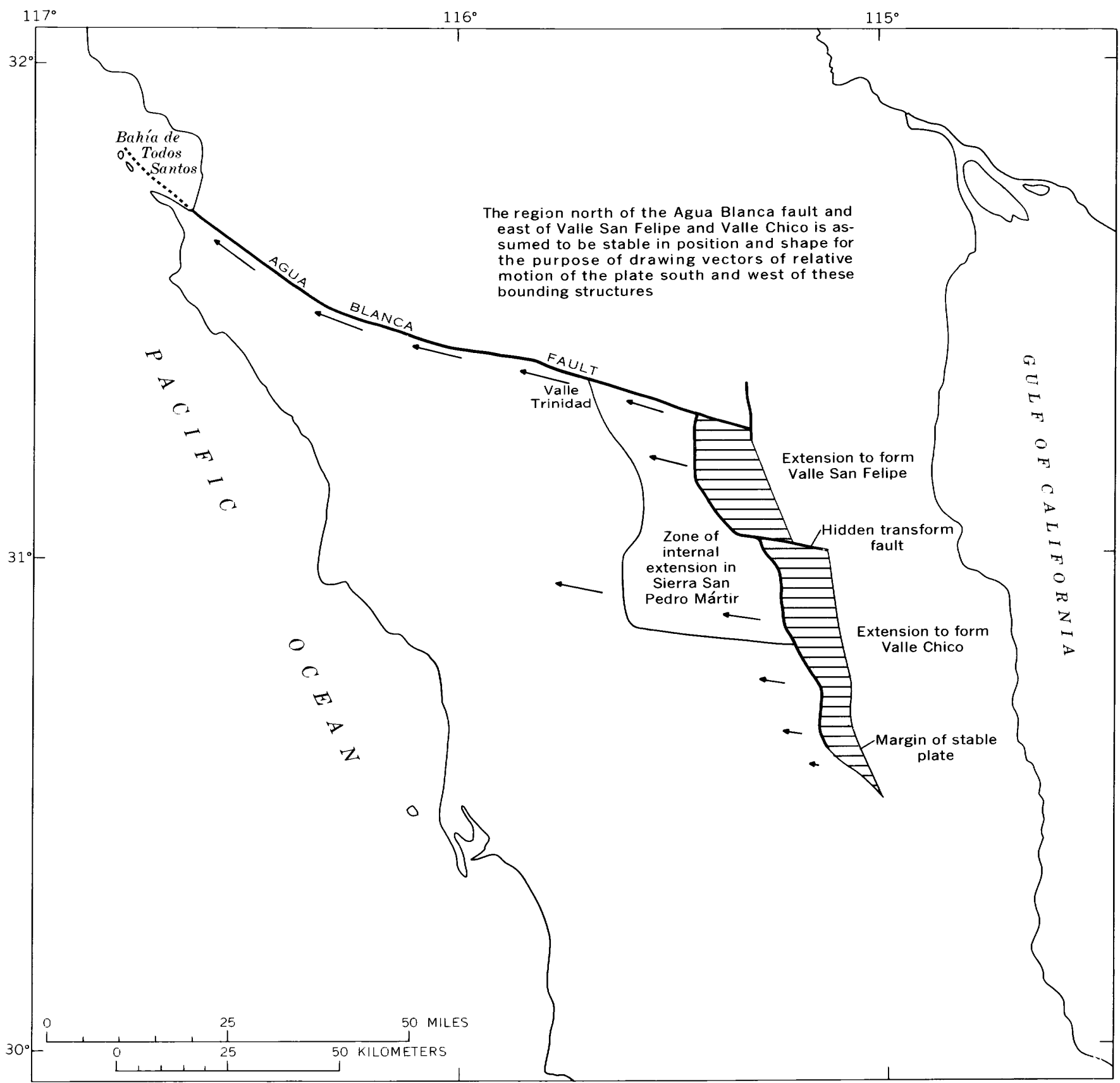

FIGURE 12. - Vectors of relative motion of the crustal plate south of the Agua Blanca fault needed to account for strike-slip faulting on the structure and for extension producing the Valle San Felipe and the Valle Chico. Map and vector scales are equal. Compare with figure 11.

strike-slip displacement on the Agua Blanca fault. Holocene displacement decreases eastward in the same sector of the Agua Blanca (Allen and others, 1960 ), so the youngest strike-slip motion may be taken up by the extension represented by this normal faulting. These normal faults are, however, too small to account for all of the Quaternary displacement on the Agua Blanca fault.
The crustal plate bounded on the north by the Agua Blanca fault is bounded on the east by the great normal-fault scarp of the Sierra San Pedro Mártir and the deep half graben of Valle San Felipe and Valle Chico. The Agua Blanca has a right-lateral Quaternary displacement of at least $5 \mathrm{~km}$, and the normal fault represents an extension of at least 4 $\mathrm{km}$. Apparently the Agua Blanca fault is the trans- 
form to the crustal extension to which the trough of Valle San Felipe and Valle Chico owes its normal faulting and deep subsidence. The plate bounded by strike-slip and normal faults has moved relatively west-northwestward away from the terrain east of the fault trough as well as past the terrain north of the Agua Blanca fault itself (figs. 11, 12). The extensional normal faulting has occurred in the lee of the drifting plate.

This transform relationship accounts for the proved displacement on the Agua Blanca fault. If, however, the actual total displacement is greater than perhaps $10 \mathrm{~km}$, then some of that amount must be transformed by structures other than the large normal-fault trough.

A transform relationship of subsidiary structures within the trough of Valle San Felipe and Valle Chico is suggested by the geometry of the trough. The constriction of the trough separating it into the halves bearing the separate names is defined by abrupt deflections of both east and west margins westward from the general north-northwestward trends. A strike-slip fault striking west-northwestward, parallel to the Agua Blanca fault, beneath the constriction would account for this geometry (fig. 12). Valle San Felipe and Valle Chico may be separate grabens, the extensional motion being transformed $8-10 \mathrm{~km}$ between them on this strike-slip fault.

No strike-slip fault leaving Valle Chico at the south is apparent on the space photographs (figs. $9,13)$. Because the set of extensional troughs and transform strike-slip faults does not appear to be complete, counterclockwise shear or rotation of the Sierra San Pedro Mártir away from Valle San Felipe and Valle Chico may be indicated. The internal deformation of the Sierra, the height of its frontal fault scarp, and the width of Valle Chico all decrease southward from the central part of the range, in accord with the inference that the amount of extension decreases in the same sector. This concept, illustrated by figure 12, if correct requires that internal deformation of the plates bounded by the Agua Blanca fault operates to prevent rotation of the southern plate away from the northern plate west of Valle Trinidad to Bahía de Todos Santos.

The young normal or left-lateral faults east of the Valle San Felipe-Valle Chico trough trend dominantly northeastward, perpendicular to the regional strike of the basement rocks and approximately $45^{\circ}$ from the extensional axes of the Valle San Felipe and Valle Chico troughs. Presumably these faults represent jostling and oblique extension of the plate east of the main zone of extension.
SIERRA JUAREZ AND LAGUNA SALADA

The eastern uplands north of the Agua Blanca fault rise northward to form the Sierra Juarez. The south end of this mountain mass is within the Apollo 6 vertical-photographs strip (figs. 7,8 ), and the northeastern part is shown by several oblique Gemini and Apollo photographs (for example, fig. 6).

The south end of the Sierra Juarez has a diffuse crestal region and gives way to the low desert to the east via irregular small mountain masses. Tre crest of the range within the vertical-photograpls strip (figs. 7, 8) consists of a low-relief surface, developed primarily on granitic rocks, from which rise irregular erosional remnants of sheets of Tertiary rolcanic rocks: stripping of the volcanics has exhumed the older and more resistant erosion surface. Thr?e postvolcanism normal faults, trending northwestward oblique to the north-northwest trend of the range, are seen on the photographs to break the eastern slope of the range and to step and tilt the volcanic sheets and the underlying erosion surface irrerularly downward.

The northern part of the Sierra Juarez is similar to the Sierra San Pedro Mártir: it consists of broad upland surfaces, generally sloping gently westward and deformed by steps which appear to include both monoclines and normal faults, and its high east normal-fault scarp faces the deeply alluviated valley of the Laguna Salada. The top of the frontel scarp has an altitude of $1,500-1,800 \mathrm{~m}$, and the bcttom is at $50-250 \mathrm{~m}$; the central part of the valley floor is below sea level.

The crestal upland and east scarp of the Sierra Juarez are in the lower right part of figure 5. The dark terrain across the base of the photograph is the wooded upland, and the slightly lighter terrain between that and the alluvial basins is the arid east scarp. The base of the scarp is shown by the photographs to be a less sharp line than that of the Sierra San Pedro Mártir: the Sierra Juarez fault apparently was much less active during late Quaternary time than was the boundary structure of the Sierra San Pedro Mártir.

The geometric similarity of the Sierra San Pedro Mártir-Valle San Felipe and the Sierra JuarezLaguna Salada structural pairs suggests common mechanisms for both. A transform mechanism is indicated for the former, and a similar mechanism also may account for the latter. The right-lateral Elsinore fault zone trends southeastward to the northwest corner of the Laguna Salada basin, and perhaps it is a transform fault related to oblique extension which produced the basin and the normal fault bounding the Sierra Juarez. The Elsinore fault, 

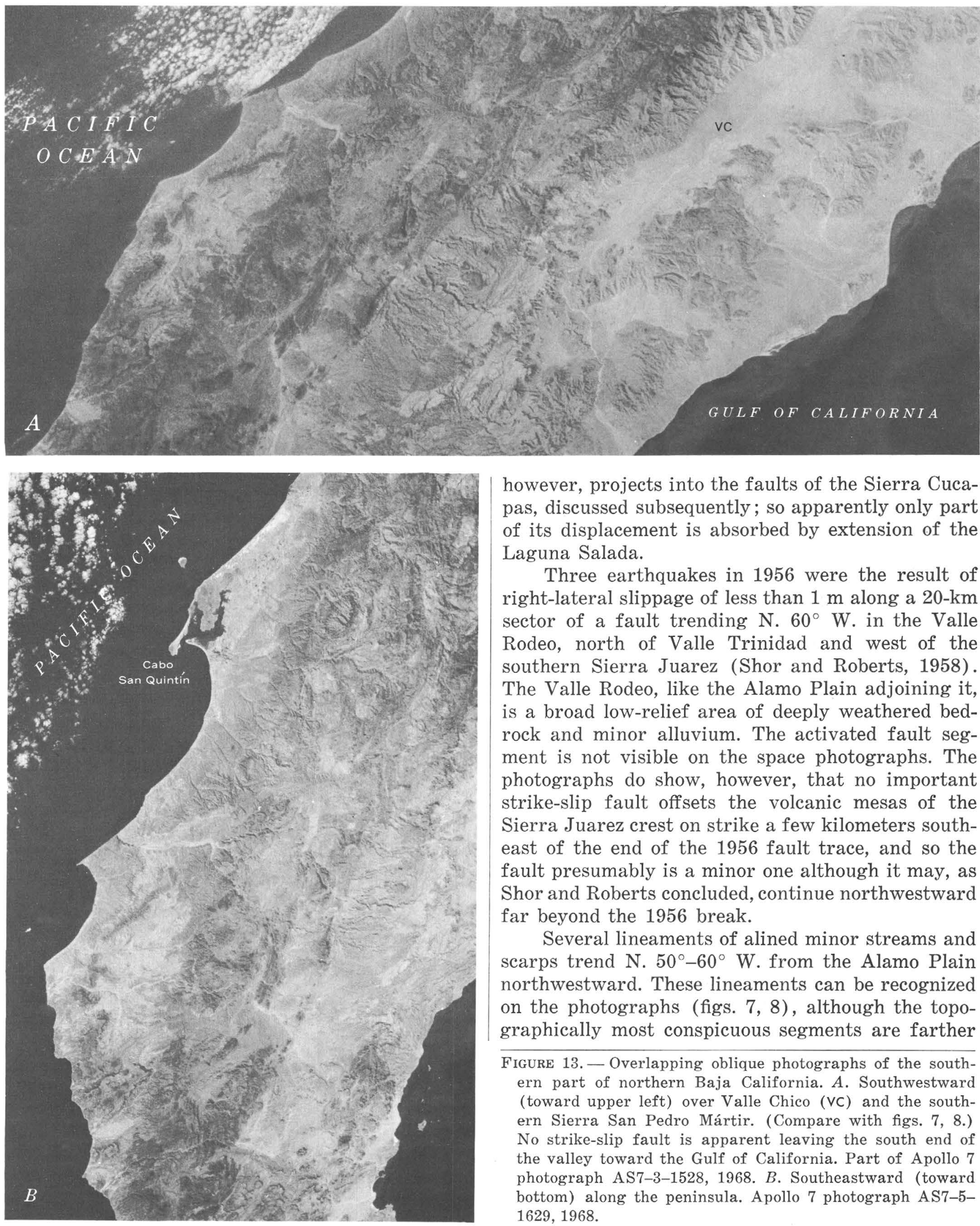

however, projects into the faults of the Sierra Cucapas, discussed subsequently; so apparently only part of its displacement is absorbed by extension of the Laguna Salada.

Three earthquakes in 1956 were the result of right-lateral slippage of less than $1 \mathrm{~m}$ along a $20-\mathrm{km}$ sector of a fault trending N. $60^{\circ} \mathrm{W}$. in the Valle Rodeo, north of Valle Trinidad and west of the southern Sierra Juarez (Shor and Roberts, 1958). The Valle Rodeo, like the Alamo Plain adjoining it, is a broad low-relief area of deeply weathered bedrock and minor alluvium. The activated fault segment is not visible on the space photographs. The photographs do show, however, that no important strike-slip fault offsets the volcanic mesas of the Sierra Juarez crest on strike a few kilometers southeast of the end of the 1956 fault trace, and so the fault presumably is a minor one although it may, as Shor and Roberts concluded, continue northwestward far beyond the 1956 break.

Several lineaments of alined minor streams and scarps trend N. $50^{\circ}-60^{\circ} \mathrm{W}$. from the Alamo Plain northwestward. These lineaments can be recognized on the photographs (figs. 7, 8), although the topographically most conspicuous segments are farther

FIGURE 13. - Overlapping oblique photographs of the southern part of northern Baja California. A. Southwestward (toward upper left) over Valle Chico (VC) and the southern Sierra San Pedro Mártir. (Compare with figs. 7, 8.) No strike-slip fault is apparent leaving the south end of the valley toward the Gulf of California. Part of Apollo 7 photograph AS7-3-1528, 1968. B. Southeastward (toward bottom) along the peninsula. Apollo 7 photograph AS7-5$1629,1968$. 
northwest, beyond the area covered by the space photographs, and perhaps mark minor strike-slip faults. These structures are not shown in figure 11 because the photographs do not provide clear evidence as to their character. None of the lineaments is visible as far southeastward as the Agua Blanca fault or the Sierra Juarez high country.

\section{SIERRA CUCAPAS}

Strikingly linear narrow valleys lace the Sierra Cucapas, east of the Laguna Salada, and are continuous throughout the range, crossing drainage divides and convergences (figs. 6,14 ). These valleys have the topographic signature of strike-slip faults. The troughs arc in a gently anastomosing subparallel array, from west-northwestward trends in the southeast to northwestward ones in the northwest. In the eastern part of the range, massive granitic rocks, and the migmatites which bound them on the east, are cut at high angles by the troughs. My brief field examination suggested right-lateral displacements of the granitic and migmatitic rocks of about $5 \mathrm{~km}$ along each of two of the troughs. The range has been mapped by Barnard (1968).

The effect of these faults is, in transform terms, to widen southward the Colorado River delta sector of the Gulf of California depression.

COLORADO RIVER DELTA FAULTS

Several of the Apollo and Gemini photographs, including those in figures 10 and 14, show a conspicuous straight fault in the delta sediments of northwesternmost Sonora. The picture best illustrating the structure is reproduced as figure 15. (The fault was also recognized on space photographs by Lowman, 1968, pl. 3, who presented an excellent color reproduction of the same photograph.) Ponding along the southwest side of the fault shows the northeast side to be relatively uplifted by at least a few meters.

The modern delta ends on the northeast against a scarp eroded by distributaries into older Quaternary river and delta materials (fig. 15; Merriam, 1965). This scarp may have been eroded back from a fault scarp formed by repeated offsets along the active fault trace visible in the photographs, or it may follow another fault strand.

Several faults were recognized on aerial photographs and in the field by Merriam (1965) near the coast in the area shown in the lower right quarter of figure 15. These are strike-slip faults with a vertical component that is generally up on the northeast side; the faults lie northeast of and parallel to the projection of the delta fault. Delta sediments have been raised at least $150 \mathrm{~m}$ by the vertical component of late Quaternary motion, and of this at least $15 \mathrm{~m}$ - the altitude of a barnacle-encrusted Indian artifact - is late Holocene (Merriam, 1965). Several of these faults that were identified by Merriam can be recognized on the space photographs, and the positions of two of them are marked by arrows in fig. 10 .

The Imperial Valley and Colorado delta region are laced by active right-lateral northwest-trending faults which have produced many severe earthquakes. The unconsolidated sediments of the delta could not long maintain a strike-slip fault trace as a conspicuous surface feature. The delta fault probably broke during the earthquake of December 31, 1934 (Biehler and others, 1964, fig. 1; Kovach and others, 1962). There was a very severe shock in 1903 "south of the Imperial Valley" (Ulrich, 1941, table 1) and a major earthquake in the delta region in 1915 (Biehler and others, 1964), either or both of which might also have resulted from surface breakage on the delta fault. Kovach, Allen, and Press (1962) suggested that this fault is the southeastern projection of the San Jacinto fault of southern California. The Sierra Cucapas and delta faults converge at a low angle (fig. 14), so the Elsinore-Cucapas and San Jacinto faults may join in the delta.

\section{VOLCANIC ROCKS}

Middle and upper Cenozoic basaltic, andesitic, and rhyolitic rocks are widespread in northern Baja California (Barnard, 1968; Gastil and others, 1969; Gastil and Krummenacher, 1970; James and LaBorde, 1969 ; Sommer and Garcia, 1970). Within the area of the vertical space photographs (figs. 7, 8, 9, $10)$, volcanic rocks are abundant in the crestal region of the Sierra Juarez and in the desert mountains to the east of it, particularly the Sierra Pintas. The volcanic rocks are conspicuous, because of their bright or dark colors, on color photographs from space, although the distinction between volcanic rocks younger than the granitic rocks and metamorphic rocks older than the granitic rocks cannot everywhere be made unambiguously.

Within the northern part of the photographed crestal area of the Sierra Juarez, the volcanic rocks form erosional remnants of extensive reddish and brownish volcanic sheets, presumably silicic welded tuffs, that stand as buttes and mesas rising above the exhumed prevolcanism erosion surface on the dominantly granitic rocks of the basement complex. Similar sheets cap normal-fault blocks and ramps stepping down the east side of the range, although the broad structure of the east slope of the range here, as defined by the attitude of the base of the volcanic rocks, appears to be monoclinal rather than 


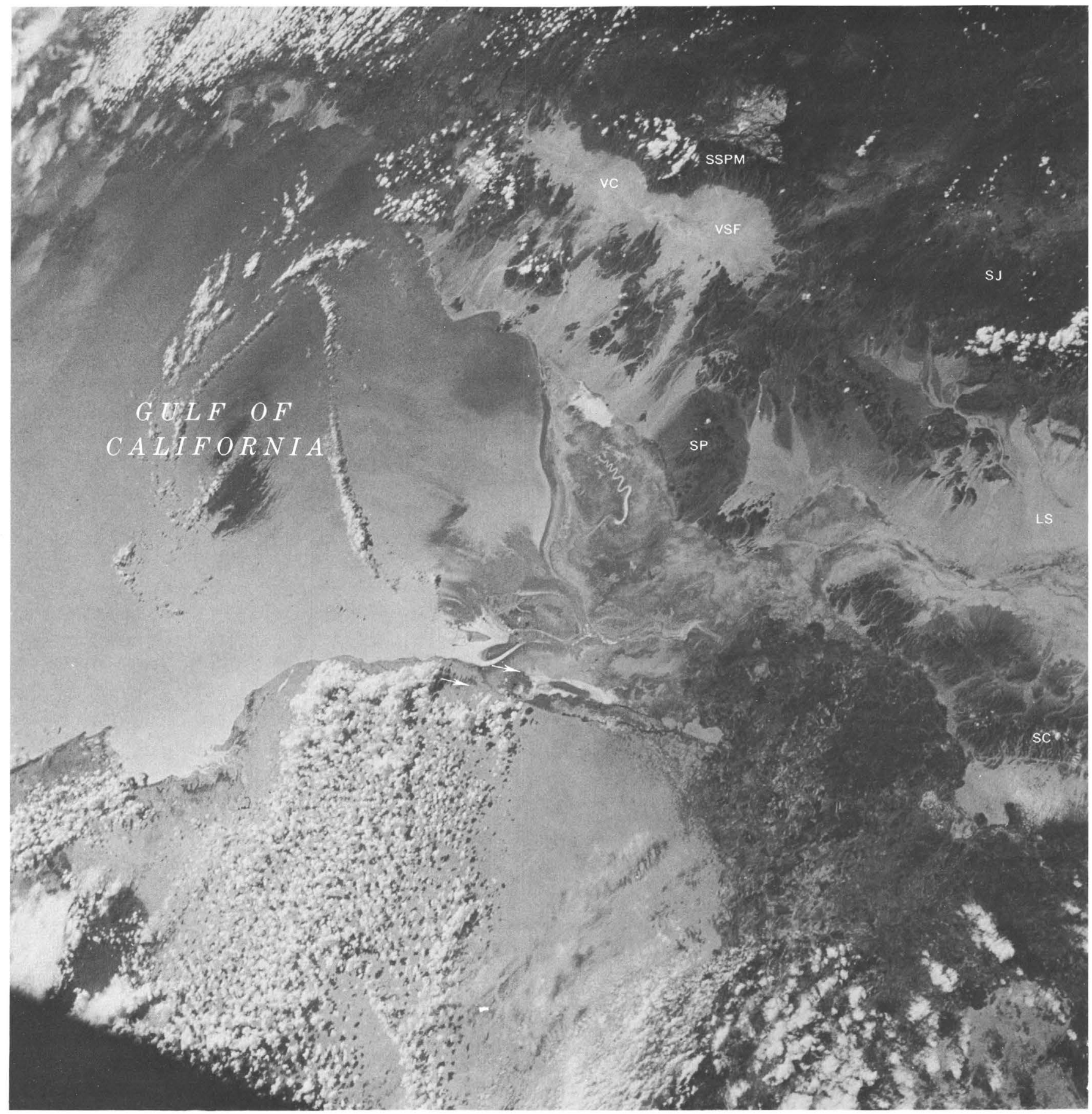

FIGURE 14. - View southward over the delta of the Colorado River. The inferred strike-slip faults (arrows) trending northwestward along the northeast side of the delta and through the Sierra Cucapas (SC) may connect in the irrigated region (dark). VSF, Valle San Felipe; VC, Valle Chico; SSPM, Sierra San Pedro Mártir; LS, Laguna Salada; SJ, Sierra Juarez; SP, Sierra Pintas. Apollo 9 photograph AS9-21-3288, 9 March 1969.

faulted. The volcanic rocks are likely of early or middle Miocene age (Gastil and others, 1969b) and appear to wholly antedate the faulting and tilting. The southern part of the photographed crestal area of the Sierra Juarez exposes thicker complexes of bright-colored volcanic rocks, which lack the conspicuous layering of the sheet volcanics to the north and may have been eroded from andesitic or dacitic stratovolcanoes, although no constructional topography is apparent. Bright-colored volcanic rocks 


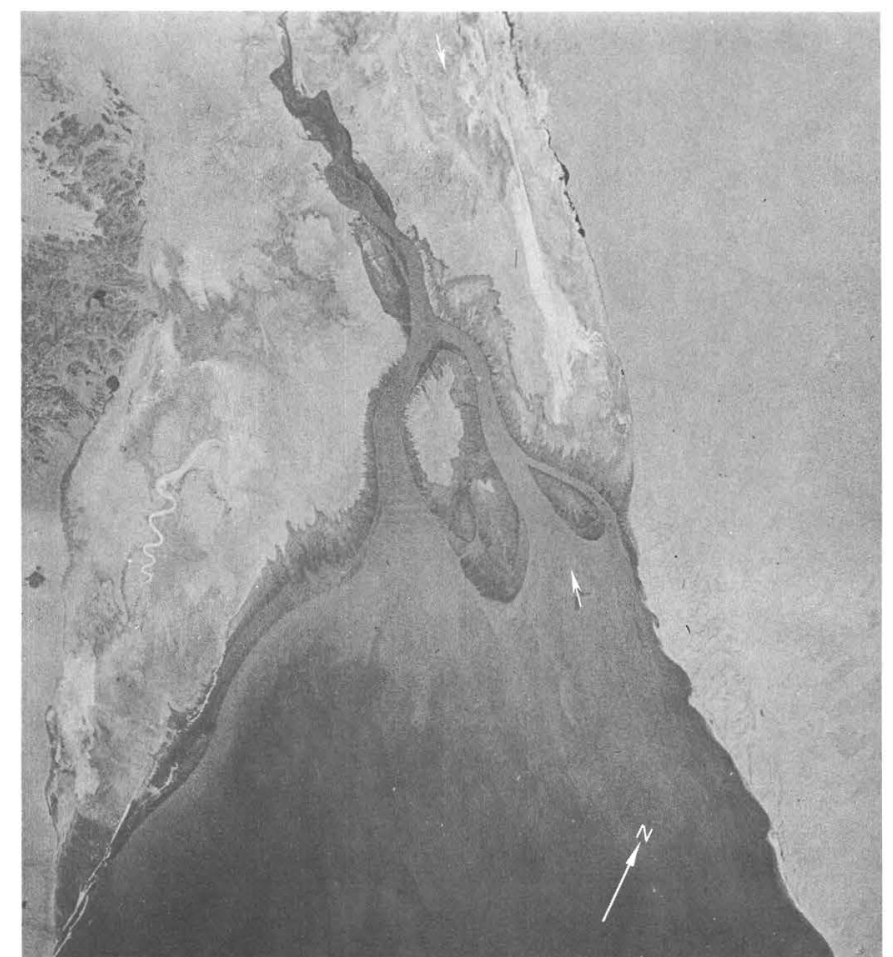

FIGURE 15. - Near-vertical photograph of the mouth of the Colorado River and the head of the Gulf of California. The desert ranges and alluvial fans of northeastern Baja California are on the left, and the sandy Altar Desert of northwestern Sonora is on the right; between them is the delta of the Colorado. The straight line between the arrows is presumably a very active strike-slip fault. Part of Gemini IV photograph, magazine 8, frame 3 (NASA numbers S-6532910 for black and white, S-65-34673 for color), taken 5 June 1965 by E. H. White.

form irregular desert mountains, notably the Sierra Pintas, east of the Sierra Juarez; these rocks also lack the even layering of some of the crestal rocks and appeared on brief ground inspection to be deeply eroded stratovolcanoes of dominantly intermediate rocks.

\section{CENTRAL BAJA CALIFORNIA}

The northern part of central Baja California is shown with fair detail on several moderate-oblique hand-held space photographs, of which the best are reproduced as figures 13,16 , and 17 . The southern portion of the central part of the peninsula is represented primarily by low-angle oblique photographs, most of which show relatively little detail; figure 18 is an exception and combines fair detail with coverage of a large region. The geology is complicated a basement complex of granitic and metamorphic rocks is overlain by Tertiary sedimentary rocks and by upper Cenozoic volcanic rocks and is disrupted by irregular basins surfaced by Quaternary sedi- ments (Hernández-S.-M. and Salas, 1968). The Quaternary basins are obvious on the pictures, and the sheetlike character of the resistant volcanic rocks permits their recognition in many places (as in fig. 17). Most of the peninsula is desert at this latitude: the west slope largely lacks the dense scrub present farther north. It will obviously be possible to much improve upon available geologic maps by interpretation of stereoscopic space photographs when such are available here, but I have not attempted to make a map from the random oblique photographs.

The pictures show clearly that no narrow topographic trough trends northwestward across the peninsula in this sector: there are no apparent crosscutting strike-slip faults analogous to the Agua Blanca fault or to the strike-slip structures of the Peninsular Ranges of California. (Crosscutting strike-slip faults have been hypothesized in this sector - for example, the Sal si Puedes and Santa Rosalía faults of Rusnak, Fisher, and Shepard (1964, fig. 4).)

In the northern part of central Baja California, there is an alinement of structural features along the axis of the peninsula (figs. $13 A, 13 B$, and 16). The prints I have studied lack resolution adequate to define satisfactorily the nature of this alinement, whose most conspicuous element is narrow dark hills. That it is not a major strike-slip fault seems indicated by the lack of its continuation in the mountainous regions to the northwest and southeast along its trend or, alternatively, by the lack of basins of possible transform character at either end.

The islands - Isla Ángel de la Guarda and Isla San Lorenzo - east of the central part of the peninsula are elongate parallel to the general trend of the Gulf coast of Baja California but are markedly disjunct to structures within it (figs. 17, 18). The islands rise from a narrow, straight submarine high that is separated from the peninsula by a straight and narrow trench 800-1,500 $\mathrm{m}$ deep (Chase, 1968). On the peninsula, a conspicuous alluviated normalfault trough, bounded on the west side by a high scarp, trends northward obliquely to the coast south of Isla Ángel de la Guarda (fig. 17). The submarine trench must mark a major fault, and in the regional context it could well be a right-lateral strike-slip fault, as Rusnak, Fisher, and Shepard (1964, p. 70) concluded.

The northeastern half of the peninsula between the parallels of $26^{\circ}$ and $30^{\circ} \mathrm{N}$. is marked by northtrending topographic elements, oblique to the northwest trend of the peninsula. A number of these elements are within the view of figure 18. One mountain front - to the left of the lower half of 


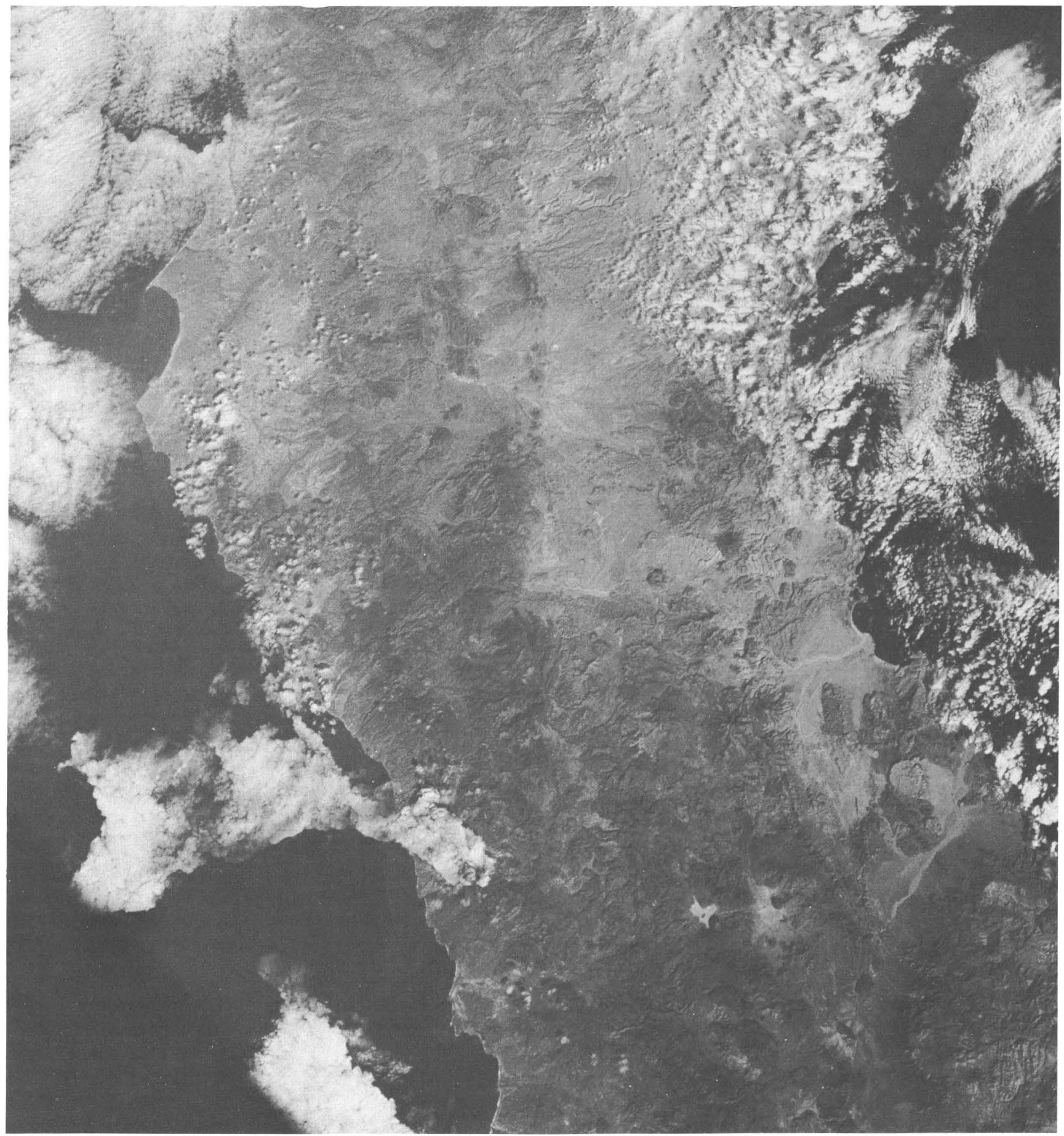

FigURE 16. - View steeply downward over the Rosario-Santa Maria sector of Baja California. North is toward top. The small basins in the lower right quarter appear to be outlined in part by normal faults. No strike-slip faults are apparent. Apollo 9 photograph AS9-21-3262, 8 March 1969.

Isla Ângel de la Guarda in figure 18 - in this system of northerly elements is obviously a young normal fault, and it is marked by a nearly straight scarp about $1,500 \mathrm{~m}$ high. (See also fig. 17.) When space photographs providing detailed coverage of this sec- tor are available, it should be possible to tell much about the extent of similar structures elsewhere among the north-trending elements. The structures could of course also be studied on conventional aerial photographs. 


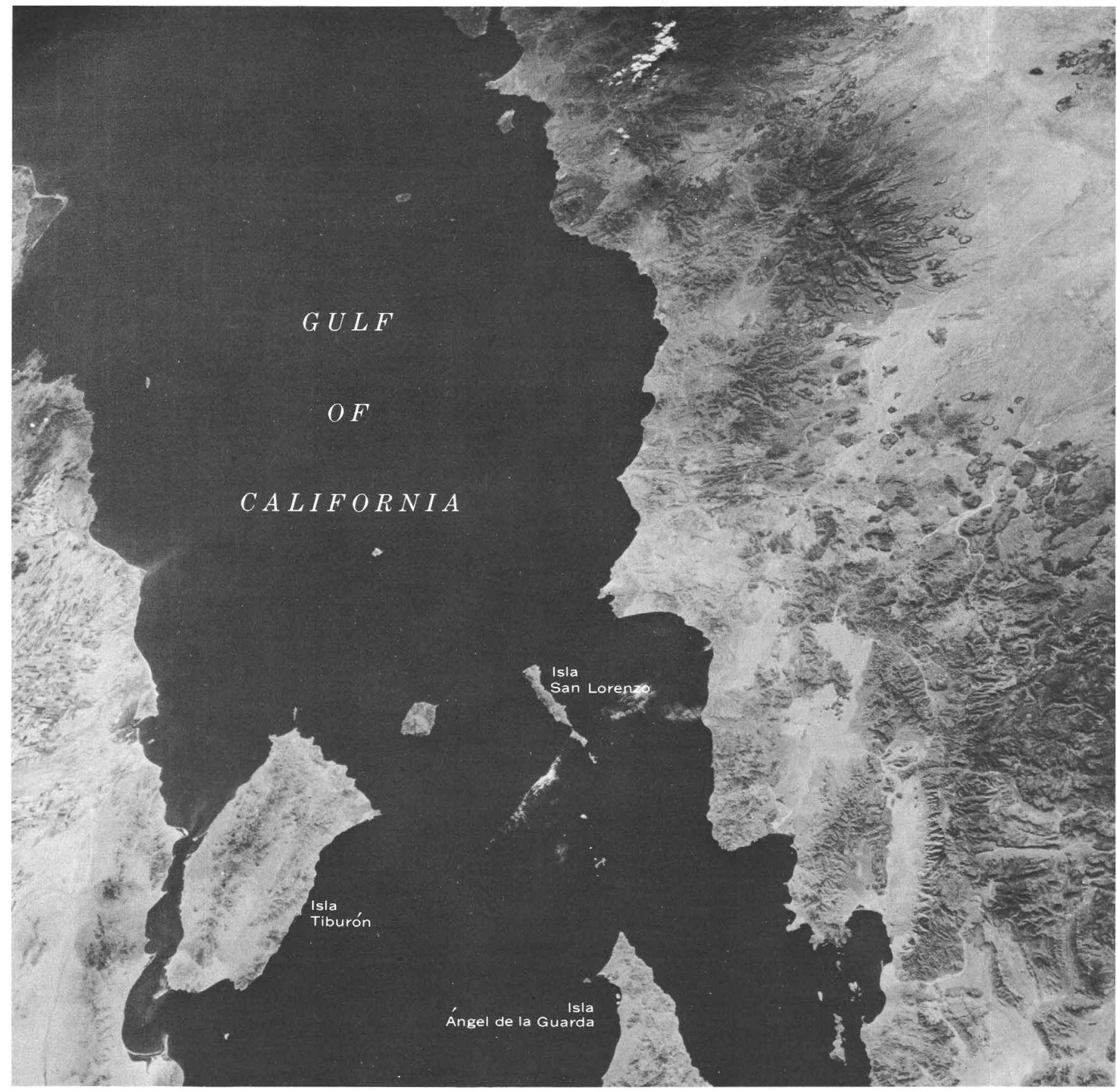

FigURE 17. - View southeastward (toward upper left) down the Gulf of California. The mainland is on the left, and Baja California is on the right. Eroded sheets of dark volcanic rocks are present in upper right quarter. Normal faulting is indicated by various scarps in the lower right part of the picture. Apollo 7 photograph AS7-5-1630, 1968.

\section{SOUTHERN BAJA CALIFORNIA}

The southern half of Baja California is but poorly covered by available space photographs. Several small parts of it are shown by near-vertical photographs, but most appear only on low-angle oblique pictures which convey relatively little information.

A possible major strike-slip fault is inferred in figure 19 to cross northward through the tip of the peninsula and thence to arc northwestward along the northeast coast, and to have a total length of at least $600 \mathrm{~km}$. Part of the evidence for this fault comes from the space photographs and part from other, published sources. The map is annotated to summarize the evidence.

A marked lineament of narrow vegetational and topographic elements crosses northward obliquely 


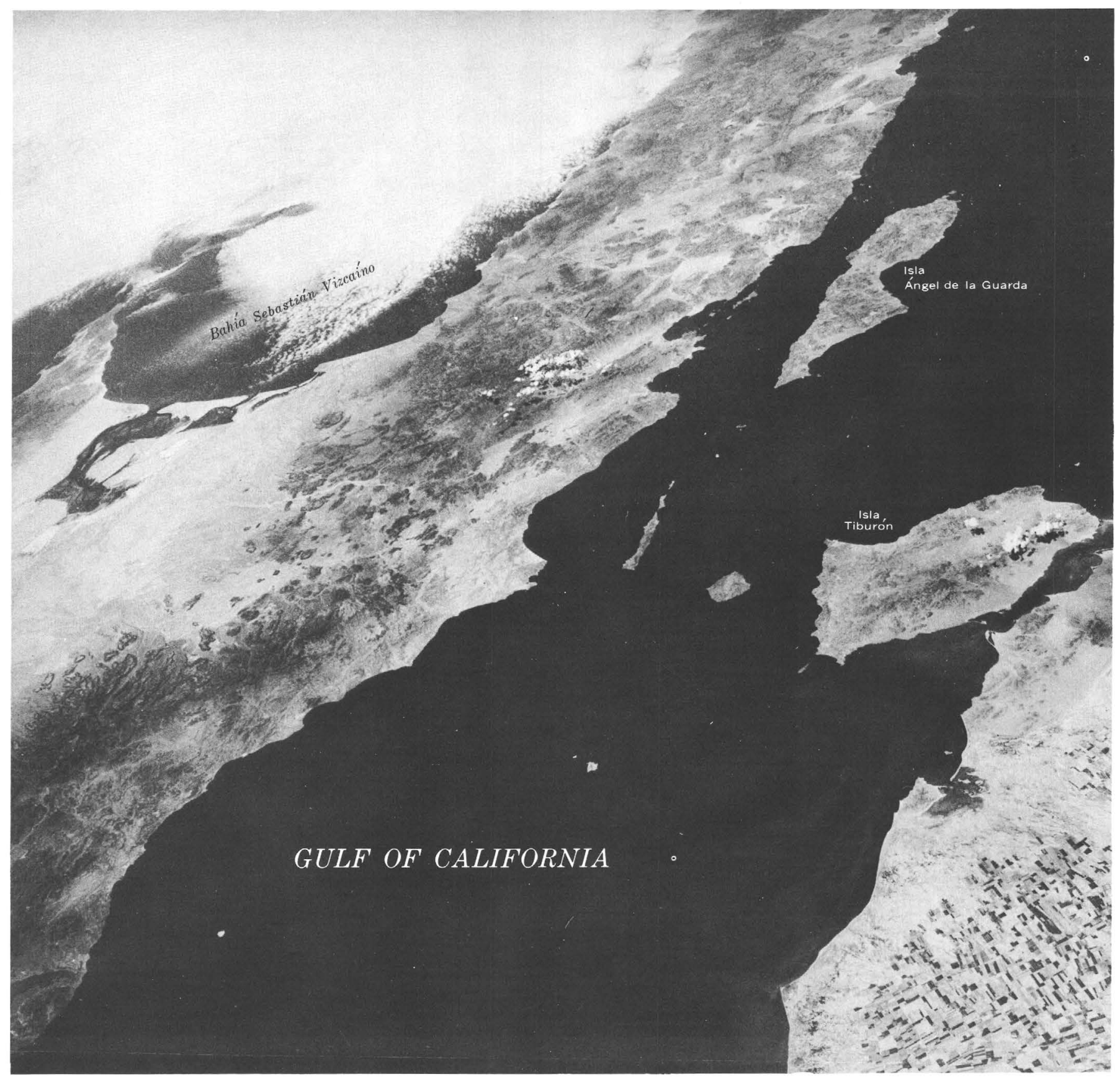

Figure 18. - Oblique view northwestward over Isla Tiburón to central Baja California. Alluviated basins in the upper half of the picture have generally northward trends, oblique to the peninsula. A conspicuous dome appears in the lower left corner. Gemini V photograph, magazine 3, frame 31 (NASA numbers S-65-45460 for black and white, S-65-45702 for color), taken 21 August 1965 by L. G. Cooper and Charles Conrad, Jr.

through the south end of the peninsula to La Paz (figs. 19, 20). The north part of this line is followed by drainage toward Bahía de la Paz, but the rest of the lineament cuts directly across westward-flowing streams, and so the line is inferred to mark a strikeslip fault.
The southward projection of this lineament is shown by continuous-seismic submarine profiling to mark a fault down the continental slope, the east side being relatively downdropped (Normark and Curray, 1968). 


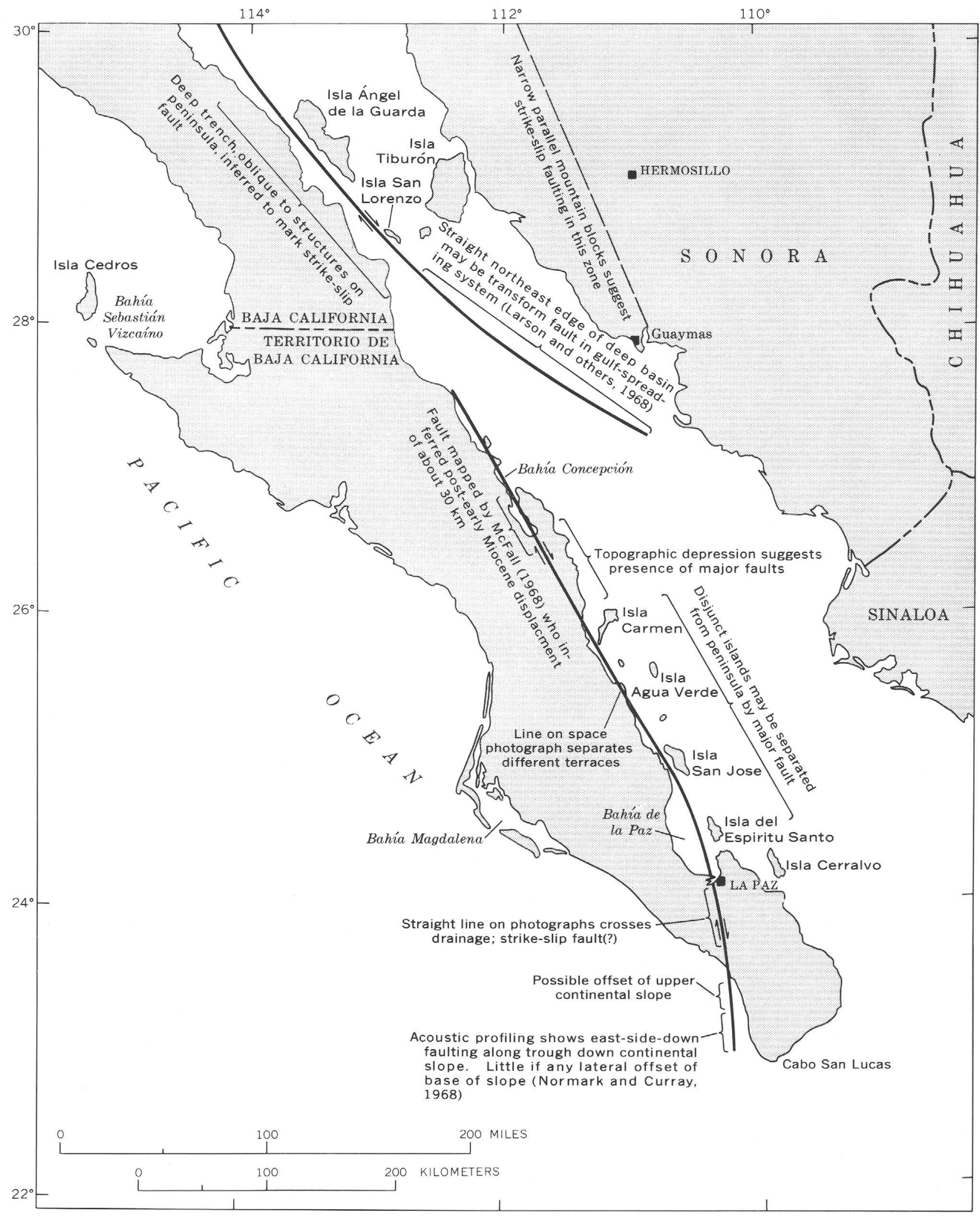

Figure 19. - Possible strike-slip faults in the region of central and southern Baja California. 


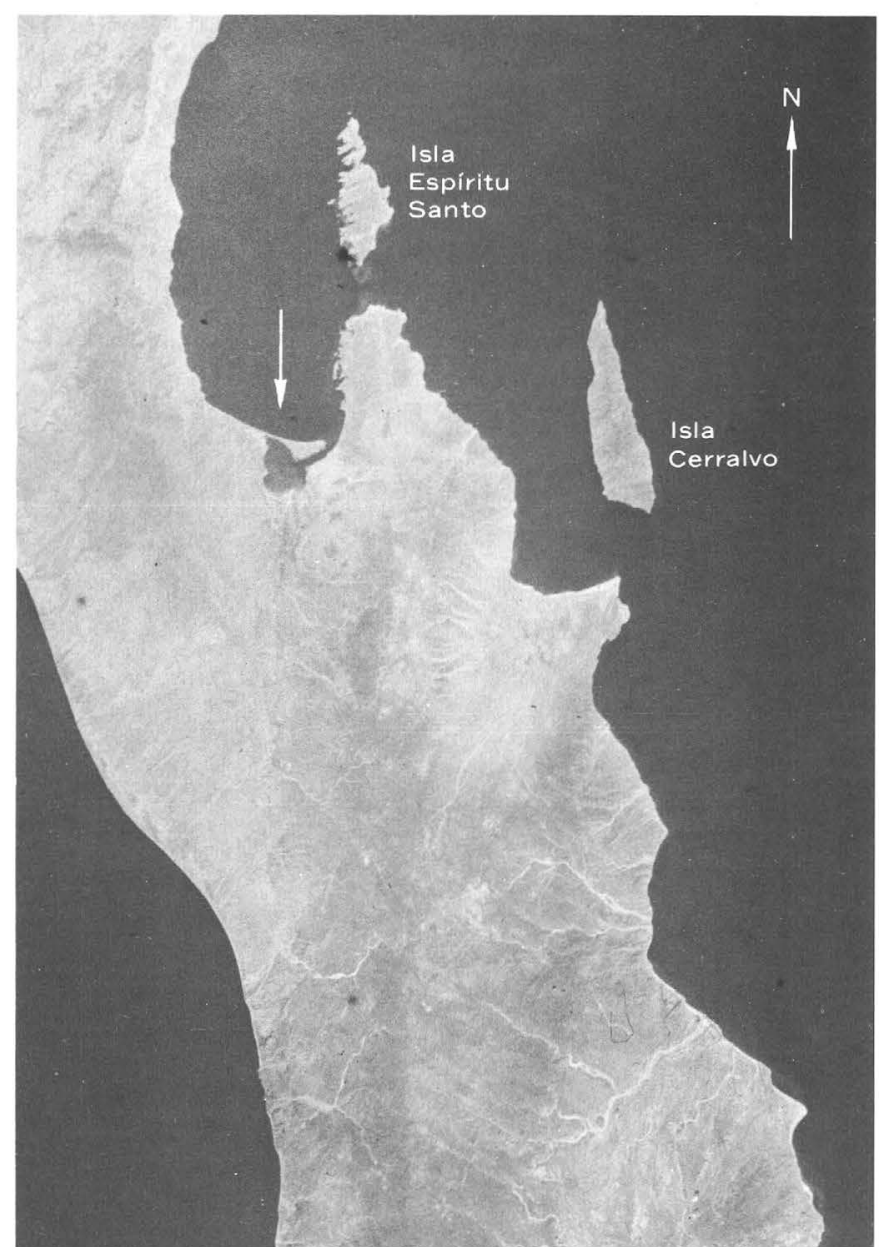

FIgURE 20. - View steeply downward to La Paz region of southern Baja California. The arrow points along a vegetational and topographic lineament which cuts obliquely across the peninsula and directly across much of the drainage pattern, and which may mark a strike-slip fault. The length of the peninsula within the picture is about $200 \mathrm{~km}$. Gemini V photograph, magazine 2, frame 39 (NASA numbers S-65-45585 for black and white, S-65-45530 for color), taken 27 August 1965 by L. G. Cooper and Charles Conrad, Jr.

McFall (1968) mapped the area about Bahía Concepción and found that bay to be developed along a strike-slip fault that trends northwestward along the Gulf coast. McFall deduced a post-early Miocene displacement of about $30 \mathrm{~km}$ along the fault, although control over the amount of movement is poor. The fault is expressed by a straight topographic trough - the onshore continuation of the bay depression - where it is exposed southeast of the bay (McFall, 1968, fig. 3). A space photograph shows this depression to be continuous southeastward to the coast west of Isla Carmen.

Continuity of faulting near the coast between La Paz and Bahía Concepción faults is suggested in figure 19, because the peninsula is bounded by the southeastward projection of the Bahía Concepción structure. Carmen, Agua Verde, San Jose, and Espiritu Santo islands are all inferred to stand east of the Bahía Concepción-La Paz fault. Rusnak, Fisher, and Shepard (1964, fig. 4 and p. 71) made the same interpretation. The Bahía Concepción-La Paz fault - if its character and continuity have been correctly inferred - may represent motion between the North American and western Pacific tectonic plates before the mouth of the present Gulf of California began to open by separation of the Cabo San Lucas terrain from mainland Mexico. (See Larson and others, 1968; McKenzie and Morgan, 1969.)

\section{REFERENCES CITED}

Allen, C. R., Silver, L. T., and Stehli, F. G., 1960, Agua Blanca fault - A major transverse structure of northern Baja California, Mexico: Geol. Soc. America Bull., v. 71, no. 4 , p. 457-482.

Allison, E. C., 1964, Geology of areas bordering Gulf of California, in Marine geology of the Gulf of CaliforniaA symposium: Am. Assoc. Petroleum Geologists Mem. 3, p. 3-29.

Barnard, F. L., 1968, Structural geology of the Sierra de los Cucapas, northeastern Baja California, Mexico, and Imperial County, California: Colorado Univ. Ph. D. thesis, 189 p.; abs. in Dissert. Abs., Sec. B, Sci. and Eng., v. 29, no. 9, p. 3360B, 1969 .

Bateman, P. C., and Wahrhaftig, Clyde, 1966, Geology of the Sierra Nevada, in Geology of northern California: California Div. Mines and Geology Bull. 190, p. 107-172.

Beal, C. H., 1948, Reconnaissance of the geology and oil possibilities of Baja California, Mexico: Geol. Soc. America Mem. 31, 138 p.

Biehler, Shawn, Kovach, R. L., and Allen, C. R., 1964, Geophysical framework of northern end of Gulf of California structural province, in Marine geology of the Gulf of California - A symposium: Am. Assoc. Petroleum Geologists Mem. 3, p. 126-143.

Chase, T. E., 1968, Sea flcor topography of the central eastern Pacific Ocean: U.S. Bur. Commercial Fisheries Circ. $291,33 \mathrm{p}$.

Cortwright, E. M., compiler and ed., 1968, Exploring space with a camera: Natl. Aeronautics and Space Adm. Spec. Pub. 168, 214 p.

Dibblee, T. W., Jr., 1967, Areal geology of the western Mojave Desert, California: U.S. Geol. Survey Prof. Paper 522, $153 \mathrm{p}$.

Estavillo, William, and Rogers, Mark, 1970, Potassium-argon dating of metamorphic and plutonic igneous rocks from San Matias Pass, Baja California, Mexico: Geol. Soc. America Abstracts with Programs, v. 2, no. 2, p. 90-91.

Gastil, R. G., 1968, Fault systems in northern Baja California and their relation to the origin of the Gulf of California, in Conference on geologic problems of San Andreas fault system, Stanford, Calif., 1967, Proc.: Stanford Univ. Pubs. Geol. Sci., v. 11, p. 283-286. 
Gastil, R. G., Allison, E. C., and Phillips, R. P., 1969a, Some geologic observations relative to the origin of the Gulf of California, in Abstracts for 1968: Geol. Soc. America Spec. Paper 121, p. 108.

$1969 \mathrm{~b}$, Geologic evidence relating to the origin of the northern half of the Gulf of California, in Pan-American symposium on the upper mantle, 1968: México, D.F., México Univ. Nac. Autónoma Inst. Geofísica, v. 2, group 2, p. 1-5.

Gastil, R. G., Allison, E. C., Phillips, R. P., and Obregon, Cezar, 1969, A new geology map of the State of Baja California, in Abstracts for 1968: Geol. Soc. America Spec. Paper 121, p. 506-507.

Gastil, R. G., and Krummenacher, Daniel, 1970, Reconnaissance potassium-argon dates for Cenozoic volcanic rocks in the State of Baja California: Geol. Soc. America Abstracts with Programs, v. 2, no. 2, p. 92-93.

Hernández-S.-M., Santiago, and Salas, G. P., 1968, Carta geologica de la Republica Mexicana: Comite Carta Geol. de Mexico, scale 1: 2,000,000.

Isacks, Bryan, Oliver, Jack, and Sykes, L. R., 1968, Seismology and the new global tectonics: Jour. Geophys. Research, v. 73 , no. 18 , p. 5855-5899.

James, A. H., and LaBorde, R. T., 1969, Geology of the Sierra Pinta, Baja California, Mexico, in Abstracts for 1968: Geol. Soc. America Spec. Paper 121, p. 517.

Jennings, C. W., compiler, 1967, Geologic map of California, Olaf P. Jenkins edition - Salton Sea sheet: California Div. Mines and Geology, scale 1: 250,000, separate explanatory sheet.

Kovach, R. L., Allen, C. R., and Press, Frank, 1962, Geophysical investigations in the Colorado delta region: Jour. Geophys. Research, v. 67, no. 7, p. 2845-2871.

Krummenacher, Daniel, and Gastil, R. G., 1970, Reconnaissance potassium argon dates for basement rocks in the State of Baja California: Geol. Soc. America, Abstracts with Programs, v. 2, no. 2, p. 109.

Larson, R. L., Menard, H. W., and Smith, S. M., 1968, Gulf of California - A result of ocean-floor spreading and transform faulting: Science, v. 161, no. 3843, p. 781-784.

LePichon, Xavier, 1968, Sea-floor spreading and continental drift: Jour. Geophys. Research, v. 73, no. 12, p. 3661-3697.

Lowman, P. D., Jr., 1966, The Earth from orbit: Natl. Geog. Mag., v. 130, no. 5, p. 644-671.

1968, Space panorama: Zurich, Switzerland, R. A. Müller, 68 pls. with text.

McFall, C. C., 1968, Reconnaissance geology of the Concepcion Bay area, Baja California, Mexico: Stanford Univ. Pubs. Geol. Sci., v. 10, no. 5, 25 p.

McKenzie, D. P., and Morgan, W. J., 1969, Evolution of triple junctions: Nature, v. 224, no. 5215, p. 125-133.
Merriam, Richard, 1965, San Jacinto fault in northwestern Sonora, Mexico: Geol. Soc. America Bull., v. 76, no. 9, p. $1051-1054$.

Morgan, W. J., 1968, Rises, trenches, great faults, and crustal blocks: Jour. Geophys. Research, v. 73 , no. 6, p. 19591982.

Nathan, Simon, 1969, Why our astronauts can't make good pictures: Pop. Photography, v. 65 , no. 2 , p. $71-75,120$ 124.

National Aeronautics and Space Administration, 1967, Earth photographs from Gemini III, IV, and V: Natl. Aeronautics and Space Adm. Spec. Pub. 129, 266 p.

Normark, W. R., and Curray, J. R., 1968, Geology and structure of the tip of Baja California, Mexico: Geol. Soc. America Bull., v. 79, no. 11, p. 1589-1600.

Rogers, T. H., compiler, 1966, Geologic map of California, Olaf P. Jenkins edition - Santa Ana sheet: California Div. Mines and Geology, scale 1:250,000, separate explanatory chart.

Rusnak, G. A., Fisher, R. L., and Shepard, F. P., 1964, Bathymetry and faults of Gulf of California in Marine geology of the Gulf of California - A symposium: Am. Assoc. Petroleum Geologists Mem. 3, p. 59-75.

Shor, G. G., Jr., and Roberts, E. E., 1958, San Miguel, Baja California Norte, earthquakes of February, 1956-a field report: Seismol. Soc. America Bull., v. 48, no. 2, p. 101-116.

Silver, L. T., Allen, C. R., and Stehli, F. G., 1969, Geological and geochronological observations on a portion of the Peninsular Range batholith of northwestern Baja California, Mexico, in Abstracts for 1968: Geol. Soc. America Spec. Paper 121, p. 279-280.

Slyker, Robert, 1969, Geologic and geophysical reconnaissance of the Valle de San Felipe region, Baja California, Mexico, in Abstracts for 1968: Geol. Soc. America Spec. Paper 121, p. 560.

Sommer, M. A., and Garcia, John, 1970, Potassium argon dates for Pliocene rhyolite sequences east of Puertocitos, Baja California: Geol. Soc. America Abstracts with Programs, v. 2, no. 2, p. 146.

Strand, R. G., compiler, 1962, Geologic map of California, Olaf P. Jenkins edition - San Diego-El Centro sheet: California Div. Mines and Geology, scale 1: 250,000, separate explanatory chart.

Ulrich, F. P., 1941, The Imperial Valley earthquakes of 1940 : Seismol. Soc. America Bull., v. 31, no. 2, p. 13-31.

Underwood, R. W., 1968, Color photography from space, in Smith, J. T., Jr., and Anson, Abraham, eds., Manual of color aerial photography [1st Ed.] : Am. Soc. Photogrammetry, p. 365-379.

Wilson, J. T., 1965, A new class of faults and their bearing on continental drift: Nature, v. 207, no. 4995, p. 343-347. 